\title{
GOMOS $\mathrm{O}_{3}, \mathrm{NO}_{2}$, and $\mathrm{NO}_{3}$ observations in 2002-2008
}

\author{
E. Kyrölä ${ }^{1}$, J. Tamminen ${ }^{1}$, V. Sofieva ${ }^{1}$, J. L. Bertaux ${ }^{2}$, A. Hauchecorne ${ }^{2}$, F. Dalaudier ${ }^{2}$, D. Fussen ${ }^{3}$, F. Vanhellemont ${ }^{3}$, \\ O. Fanton d'Andon ${ }^{4}$, G. Barrot ${ }^{4}$, M. Guirlet ${ }^{4}$, T. Fehr ${ }^{5}$, and L. Saavedra de Miguel ${ }^{5}$ \\ ${ }^{1}$ Finnish Meteorological Institute, Earth Observation, Helsinki, Finland \\ ${ }^{2}$ Laboratoire Atmosphères, Milieux, Observations Spatiales, Université Versailles St.-Quentin, CNRS-INSU, \\ Verrières-le-Buisson, France \\ ${ }^{3}$ Institut d'Aéronomie Spatiale de Belgique, Brussels, Belgium \\ ${ }^{4}$ ACRI-ST, Sophia Antipolis, France \\ ${ }^{5}$ European Space Research Institute (ESRIN), European Space Agency, Frascati, Italy
}

Received: 18 December 2009 - Published in Atmos. Chem. Phys. Discuss.: 1 February 2010

Revised: 9 June 2010 - Accepted: 17 August 2010 - Published: 20 August 2010

\begin{abstract}
The Global Ozone Monitoring by Occultation of Stars (GOMOS) instrument onboard the European Space Agency's ENVISAT satellite measures ozone, $\mathrm{NO}_{2}$, $\mathrm{NO}_{3}, \mathrm{H}_{2} \mathrm{O}, \mathrm{O}_{2}$, and aerosols using the stellar occultation method. Global coverage, good vertical resolution and the self-calibrating measurement method make GOMOS observations a promising data set for building various climatologies and time series. In this paper we present GOMOS nighttime measurements of ozone, $\mathrm{NO}_{2}$, and $\mathrm{NO}_{3}$ during six years 2002-2008. Using zonal averages we show the time evolution of the vertical profiles as a function of latitude. In order to get continuous coverage in time we restrict the latitudinal region to $50^{\circ} \mathrm{S}-50^{\circ} \mathrm{N}$. Time development is analysed by fitting constant, annual and semi-annual terms as well as solar and QBO proxies to the daily time series. Ozone data cover the stratosphere, mesosphere and lower thermosphere (MLT). $\mathrm{NO}_{2}$ and $\mathrm{NO}_{3}$ data cover the stratosphere. In addition to detailed analysis of profiles we derive total column distributions using the fitted time series.

The time-independent constant term is determined with a good accuracy (better than 1\%) for all the three gases. The median retrieval accuracy for the annual and semi-annual term varies in the range 5-20\%. For ozone the annual terms dominate in the stratosphere giving early winter ozone maxima at mid-latitudes. Above the ozone layer the annual terms change the phase which results in ozone summer maximum up to $80 \mathrm{~km}$. In the MLT the annual terms dominate up
\end{abstract}

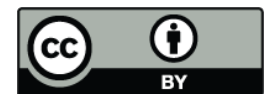

Correspondence to: E. Kyrölä (erkki.kyrola@fmi.fi) to $80 \mathrm{~km}$ where the semiannual terms start to grow. In the equatorial MLT the semi-annual terms dominate the temporal evolution whereas in the mid-latitude MLT annual and semiannual terms compete evenly. In the equatorial stratosphere the QBO dominates the time development but the solar term is too weak to be determined. In the MLT above $85 \mathrm{~km}$ the solar term grows significantly and ozone has 15-20\% dependence on the solar cycle. For $\mathrm{NO}_{2}$ below $32 \mathrm{~km}$ the annual summer maxima dominates at mid-latitudes whereas in the equatorial region a strong QBO prevails. In northern mid-latitudes a strong solar term appears in the upper stratosphere. For $\mathrm{NO}_{3}$ the annual variation dominates giving rise to summer maxima. The $\mathrm{NO}_{3}$ distribution is controlled by temperature and ozone.

\section{Introduction}

GOMOS (Global Ozone Monitoring by Occultation of Stars) is a stellar occultation instrument onboard the ENVISAT satellite (see Bertaux et al. (1991, 2000, 2004); Bertaux et al. (2010); Kyrölä et al. (2004); ESA (2001), http://envisat.esa. int/handbooks/gomos/ and other articles of this special volume). GOMOS measurements start at altitude of $130 \mathrm{~km}$ and the first few measurements are used to determine star's undisturbed spectrum (the reference spectrum). The horizontal transmission spectra are calculated from the star spectra measured through the atmosphere and the reference spectrum. The integration time is $0.5 \mathrm{~s}$, which gives the altitude sampling resolution of $0.5-1.6 \mathrm{~km}$ depending on the tangent altitude and the azimuth angle of the measurement. GOMOS

Published by Copernicus Publications on behalf of the European Geosciences Union. 
measures during day and night but only nighttime measurements have been validated so far.

The spectral ranges of GOMOS detectors are $248-690 \mathrm{~nm}$, $755-774 \mathrm{~nm}$, and $926-954 \mathrm{~nm}$, which make it possible to retrieve vertical profiles of $\mathrm{O}_{3}, \mathrm{NO}_{2}, \mathrm{NO}_{3}, \mathrm{H}_{2} \mathrm{O}, \mathrm{O}_{2}$, and aerosols. In this work we are concentrating on $\mathrm{O}_{3}, \mathrm{NO}_{2}, \mathrm{NO}_{3}$ and they are retrieved from the UV-visible spectral range $248-690 \mathrm{~nm}$. The retrieved ozone profiles have $2 \mathrm{~km}$ vertical resolution below $30 \mathrm{~km}$ and $3 \mathrm{~km}$ above $40 \mathrm{~km} . \mathrm{NO}_{2}$ and $\mathrm{NO}_{3}$ have $3 \mathrm{~km}$ vertical resolution at all altitudes. The details of the retrieval algorithms and data quality are discussed in Kyrölä et al. (2010); Tamminen et al. (2010), http: //envisat.esa.int/dataproducts/gomos and in other articles of this special volume.

GOMOS measurements provide a possibility to investigate nighttime global vertical distributions of ozone, $\mathrm{NO}_{2}$, and $\mathrm{NO}_{3}$ distributions from the tropopause up to the mesosphere and even to the lower thermosphere (ozone only). We have earlier presented ozone distributions for the year 2003 in Kyrölä et al. (2006) and $\mathrm{NO}_{2}$, and $\mathrm{NO}_{3}$ distributions in Hauchecorne et al. (2005). Now we can extend the analysis over the six year period 2002-2008. The longer period makes it possible to study various natural cycles in the data. We will retrieve annual and semi-annual variation as well as variation due to the solar cycle and the quasi-biennial oscillation (QBO). The period consider is, however, too short to study anthropogenic trends in data. Besides providing new insights to the atmospheric dynamics and chemistry, the analysis gives valuable information about the GOMOS product quality and the consistency of the data sets.

In Sect. 2 we present the selection of data used for analysis. The method used in the time series fitting is detailed in Sect. 3. Sections 4-6 show results for ozone, $\mathrm{NO}_{2}$ and $\mathrm{NO}_{3}$, respectively. For each gas we present first time evolution of profiles using monthly and 20-degree latitudinal averages. The times series fitting is based on daily data and 10-degree latitudinal averages. We show the time-averaged constant term and various cyclic components of the vertical profiles. We also calculate vertical column densities using the time series fits of profiles.

\section{Selection of data}

Like for all new instruments, a lot of effort has been targeted to GOMOS geophysical validation and comparisons with results from other satellite instruments. GOMOS data validation activity has been carried out since the summer of 2002. A comprehensive validation of ozone profiles against ground-based and balloon-borne instruments has been presented in Meijer et al. (2004). Results show that in dark limb GOMOS ozone profile data agree very well with the correlative data: between 14 and $64 \mathrm{~km}$ altitude their differences show only a small (2.5-7.5\%) negative bias (GOMOS smaller than the correlative data) with a standard deviation of
11-16\% (19-63 km). From comparisons with other satellite instrument we can mention, for example, the extensive ACE validation study in Dupuy et al. (2009) and the GOMOSMIPAS comparison including also mesospheric altitudes in Verronen et al. (2005). GOMOS $\mathrm{NO}_{2}$ measurements have been compared with HALOE in Hauchecorne et al. (2005), with MIPAS in Verronen et al. (2009) and with ACE-FTS in Kerzenmacher et al. (2008). For $\mathrm{NO}_{3}$ we have validation with a balloon borne instrument in Renard et al. (2008).

In this work we use GOMOS dark limb measurements only by requiring the solar zenith angle at the tangent point to be greater than $107^{\circ}$. In Fig. 1 we have shown the distribution of GOMOS nighttime measurements during 2002-2009. The good coverage of the winter poles and the missing coverage of the summer poles are evident. During May-June 2003 and December-August 2005 GOMOS suffered from a malfunctioning of the pointing system. In 2003 this can be seen only as a moderate decrease in the number of measurements but in 2005 a real gap in the measurements was produced. New pointing system related problems appeared during 2009 but this study is restricted to 2002-2008. The instrumental problems of GOMOS have forced to restrict the azimuth range of the pointing system from the original $-10^{\circ}$ to $90^{\circ}$ (measured with respect to the antivelocity vector of ENVISAT) to a window of $20^{\circ}$ with a variable center. These changes mean that the selection of stars has not been constant during the time frame of this study.

The solar zenith angle limit $107^{\circ}$ together with the ability of GOMOS to follow and measure stars outside the orbital plane of ENVISAT leads to a variation in the local hour of measurements. This is important for measurements of diurnally varying constituents $\mathrm{NO}_{2}, \mathrm{NO}_{3}$ and ozone in the MLT. ENVISAT crossing times of the equator are 10:00 and 22:00 local time. GOMOS tangent point local times cover $1.5 \mathrm{~h}$ in the equator and $3 \mathrm{~h}$ at mid-latitudes as shown in Fig. 2.

To assure the reliability of GOMOS data during the whole time period considered, we have paid special attention to the quality of retrievals from each star individually. In Kyrölä et al. (2006) we studied the quality of GOMOS measurements during 2003 and found that stars with magnitude weaker than 1.9 (i.e. magnitude larger than) and cooler than $7000 \mathrm{~K}$ may easily fail to capture the whole ozone profile 15$100 \mathrm{~km}$. During the course of time GOMOS S/N-ratios have decreased due to aging of the instrument. We have examined data quality for the 6 year period 2002-2008 and compared, for example, time series formed by individual stars. In order to guarantee data quality and consistency over the whole time period considered we have removed all ozone measurements from 57 different stars. The temperatures and magnitudes of these stars fulfill approximately the limits mentioned above. For $\mathrm{NO}_{2}$, and $\mathrm{NO}_{3}$ all stars were used without regard of magnitude or temperature of the stars. In all data sets we rejected occultations with the obliquity angle (derived from the angle between the occultation plane and the orbital plane 


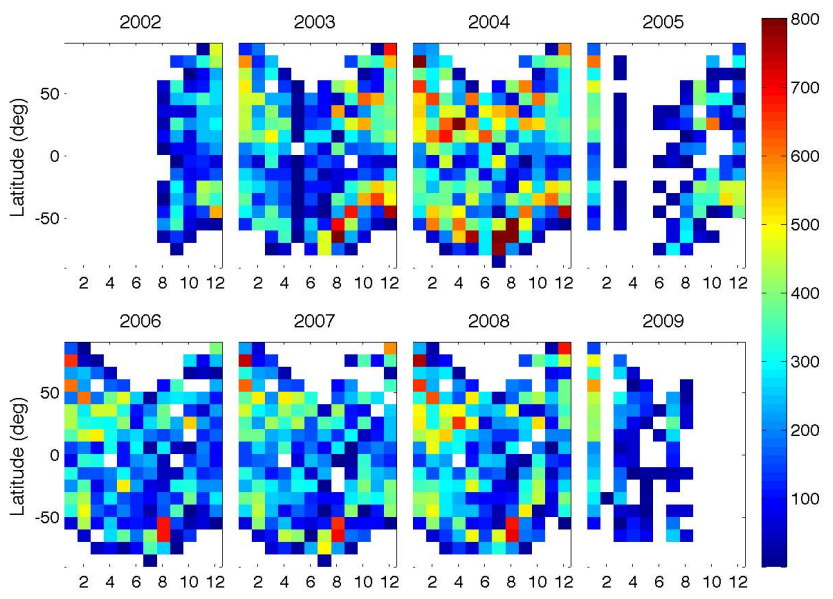

Fig. 1. Monthly number of dark limb occultations (solar zenith angle greater than $107^{\circ}$ ) in 28 August 2002-8 August 2009 as a function of time and latitude. Measurements have been collected monthly to the $10^{\circ}$ latitudinal grid. Occultations that have ended before the $20 \mathrm{~km}$ tangent height or that have the obliquity angle larger than $80^{\circ}$ have been disregarded. The grid cells that have fewer than 2 measurements carry white colour.

of ENVISAT) larger than $80^{\circ}$. The total number of dark limb occultations 2002-2008 were then 277449 for $\mathrm{NO}_{2}$ and $\mathrm{NO}_{3}$ and 173223 for ozone.

In the monthly and daily time series plots and analysis we have adopted the following data gridding:

- Vertical: data is linearly interpolated to a uniform $1 \mathrm{~km}$ grid $15-100 \mathrm{~km}$. Flagged data points are not used in the analysis. Ozone profiles from $57 \mathrm{cool}$ and dim stars were not used in statistical calculations.

- Latitudinal: in monthly time series we have used $20^{\circ}$ latitudinal bands. In time series analysis we have used 10-degree latitude bands with the exception of the equatorial belt $10^{\circ} \mathrm{S}-10^{\circ} \mathrm{N}$. Time series analysis is done for the region $50^{\circ} \mathrm{S}-50^{\circ} \mathrm{N}$ where no seasonal data voids exist.

- Zonal: data are zonally averaged in latitude bands mentioned.

- Time: we have used monthly time step to present the overall behaviour of profiles in time. The time period is 28 August 2002-8 August 2009. In time series analysis daily step is used. The time period is1 September 200231 August 2008.

As a statistical average we have used median as the median is more robust against outliers than the normal mean estimator (see Kyrölä et al. (2006) for the comparison of the mean,

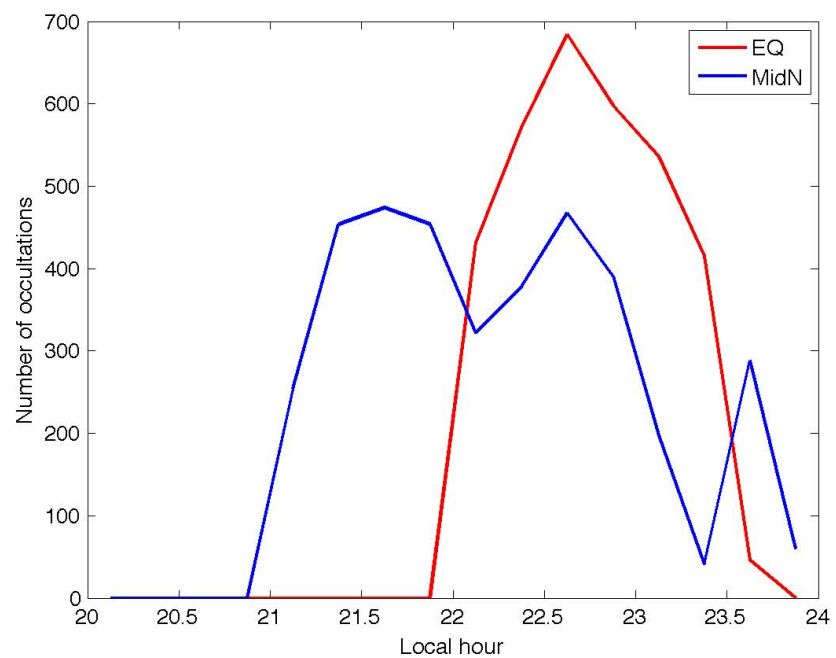

Fig. 2. Number of occultations as a function of the local time for GOMOS dark limb occultations (solar zenith angle greater than $107^{\circ}$ ) in 2004 for two latitude belts. The red line: $5^{\circ} \mathrm{S}-5^{\circ} \mathrm{N}$, the blue line: $40^{\circ} \mathrm{N}-50^{\circ} \mathrm{N}$.

the weighted mean and the median). The uncertainty of the median value is estimated by the formula

$\Delta \rho=\frac{\left(q_{3}-q_{1}\right)}{1.349 \sqrt{N}} \sqrt{\frac{\pi N}{2(N-1)}}$

The quartile distance $q_{3}-q_{1}\left(q_{3}\right.$ and $q_{1}$ are $75 \%$ and $25 \%$ percentiles, respectively) has been divided by 1.349 in order to take into account the relationship of the quartile distance to the standard deviation in the normal distribution limit. This scaled quartile distance is also used to measure the variability of data. The last factor, where $N$ is the number of cases, takes into account the inefficiency of the median estimator (see http://mathworld.wolfram.com/StatisticalMedian.html).

The minimum number of measurements needed for statistical estimation has been set to 5 . For smaller number of measurements we have ignored the contribution. Typical median number of measurements in the equatorial 20-degree latitude belt is 280 in a month. In a day the corresponding median is 14.

The GOMOS data used for this analysis are produced by the ESA Level 2 operational processor version 5. This version deviates only slightly from the earlier processor version 4 . The upcoming version 6 improves the level 1 calibration and implements the so-called full covariance matrix in the spectral inversion. The calibration update may somewhat alleviate the problem with weak and cool stars and then increase the number of useful occultations. The full covariance matrix will make the GOMOS error estimates more realistic. In this work we will not use error estimates in analysis. We expect, therefore, that the results obtained in this work can be compared to earlier results and that they remain relevant for future studies using the upcoming processor version. 


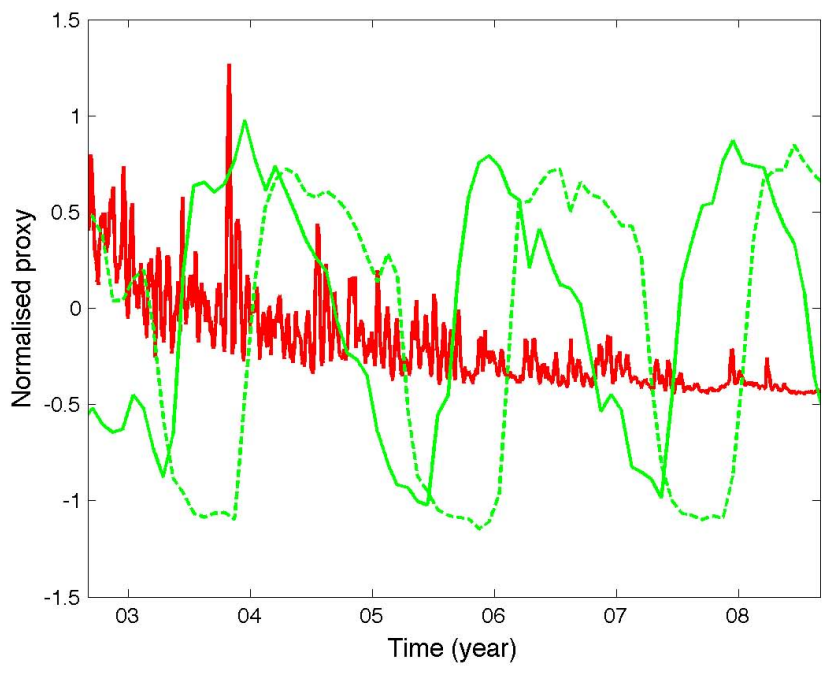

Fig. 3. Normalised daily proxies (see Eq. 3) as a function of time. The solar F10.7 cm radio flux (red line) serves a solar proxy. The winds at $10 \mathrm{hPa}$ (solid green line) and $30 \mathrm{hPa}$ (dashed green line) are proxies for the QBO effects.

\section{Methods}

The time series analysis is based on the fitting the daily median profiles $\rho(z, t)$ ( $z=$ altitude, $t=$ time $)$ in each latitude belt with the following model:

$$
\begin{aligned}
\rho^{\mathrm{fit}}(z, t) & = \\
& c(z)+s(z) F_{10.7}(t)+q_{1}(z) F_{\mathrm{qbo}}^{10}(t)+q_{2}(z) F_{\mathrm{qbo}}^{30}(t) \\
& +\sum_{n=1}^{2}\left(a_{n}(z) \cos (n w t)+b_{n}(z) \sin (n w t)\right)
\end{aligned}
$$

where $w=2 \pi / 365.25$ (1/day). This series includes three geophysical proxies. $F_{10.7}$, the solar $10.7 \mathrm{~cm}$ radio flux, is a proxy for solar influence on the middle atmosphere. $F_{\text {qbo }}^{10}$ and $F_{\mathrm{qbo}}^{30}$ are the equatorial winds at $10 \mathrm{hPa}$ and at $30 \mathrm{hPa}$, respectively. They are proxies for quasi-biennial effects (QBO). The observational basis for these proxies are discussed in Harris et al. (1999) and WMO (2007) and references therein.

We have normalised the solar and QBO terms in Eq. (2) as

$$
f(t)=2(f(t)-\langle f(t)\rangle) /\left(f_{\max }-f_{\min }\right)
$$

where $<>$ represents average over the six year period considered. Normalised proxies are shown in Fig. 3. Note that for the solar term many authors have adopted a convention where changes are measured in one hundred F10.7 units. F10.7 values have decreased from about 180 units in 2002 to 67 units in 2008 i.e., the change is 113 units. Note also that the declining phase of the solar cycle during our data period has been unusually long. A time delay in a QBO proxy is often introduced for non-equatorial regions. Using two QBO terms, that are almost in quadrature in time (see Fig. 3), makes the time delay unnecessary.
The purpose of the normalisation in Eq. 3 is to make all the coefficients directly comparable with each other. Moreover, by selecting the time period to be exactly whole number of years (6 years 1 September 2002-31 August 2008) the time average of the series $\rho^{\text {fit }}$ equals to the constant term. Notice that this average differs from the time average of the measured GOMOS data because of gaps in data whereas the time series in Eq. (2) is defined for all the days of the time period considered.

A linear trend term is manifestly missing from the time series Eq. (2). Looking at the solar proxy in Fig. 3 we can see that in the time period considered, the time smoothed solar proxy deviates only slightly from a linear trend. The linear and solar term are, therefore, highly similar. We have selected the solar term over the linear term as the former has more structure in time and therefore stronger "fingerprint".

In the case of stratospheric ozone the annual term in Eq. (2) can be justified because of the annual variation of the Brewer-Dobson meridional circulation and the annual variation of the solar insolation. In the mesosphere the meridional pole-to-pole circulation changes the direction semiannually and this is one justification for the semi-annual term in Eq. (2). Adding higher harmonic terms does not significantly improve the quality of fits.

Instead of the harmonic terms we could have used physically more direct proxies. For example, the strength of the Brewer-Dobson circulation has been explained by the estimate of the Eliassen-Palm flux at $100 \mathrm{hPa}$ in Dhomse et al. (2006). We tested this possibility but no additional benefit in fitting was obtained.

Retrieving the time series coefficients is done by using the weighted least squares fitting. The weights are the estimated data covariances for each day. In our analysis we use the number densities (at geometrical altitudes) because they are the natural units for densities retrieved from GOMOS measurements. We have also experimented with fitting mixing ratio data but no clear improvements in the fit quality were evident. The monthly time series of the mixing ratios on pressure surfaces can be found at http://fmilimb.fmi.fi/.

The quality of the fitting has first been checked visually. More quantitative measures used are the error estimates from fitting. We have checked the autocorrelation functions for the fitting residuals and found them reasonably close to normal. We have also studied $\chi^{2}$ values and the coefficient of determination $R^{2}$ (see http://en.wikipedia.org/wiki/ Coefficient_of_determination). The last mentioned quantity has turned out to be the most useful measure. The significance of the time series components have been investigated by fitting various component configurations and inspecting the changes in the $R^{2}$ values. As a final check for results we have done fitting using also monthly time series. Monthly and daily fits give generally fitting components that are very close to each other. 


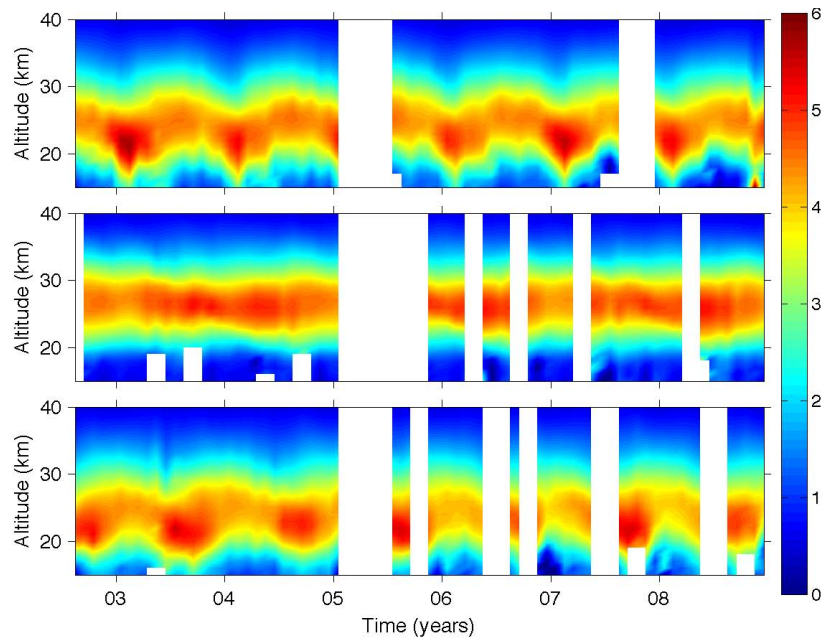

Fig. 4. Monthly ozone number density in the stratosphere in three latitude belts as a function of time and altitude. The density is scaled by $10^{12} \mathrm{~cm}^{-3}$. The time covered is 1 August 2002-31 December 2008. Latitude belts: $30^{\circ} \mathrm{N}-50^{\circ} \mathrm{N}$ (top), $10^{\circ} \mathrm{S}-10^{\circ} \mathrm{N}$ (middle), $30^{\circ} \mathrm{S}-50^{\circ} \mathrm{S}$ (bottom). White space in the panels means that there are not enough data available.

\section{Ozone}

In Fig. 4 we show the time development of the ozone number density in the stratosphere based on monthly medians and 20-degree latitude belts. The evident variation in time is a seasonal cycle at mid-latitudes. During winter and spring the ozone layer moves downwards and quite a sharp peak protrudes towards the tropopause in early winter at the northern mid-latitudes. At the same time ozone densities in the layer increase. At southern mid-latitudes these changes are somewhat smoother. These changes are consequences of the large scale Brewer-Dobson circulation of ozone from the equatorial region to high-latitudes. During summer the ozone layer retreats to higher altitudes. The equatorial ozone layer remains relatively stable in time.

Figure 5 shows the time development of ozone in the MLT. A clear semi-annual variation of the second ozone maximum appears at all latitudes. The strongest variation and highest values are seen in the equatorial distribution with maxima around the equinox times. At higher latitudes the semiannual peaks seem to be slightly merging through the winter season. The spring peak seems to form at somewhat higher altitude than the fall peak. During the six years of observations the second maximum seems to be weakening.

The overall latitudinal distribution of ozone at $20 \mathrm{~km}$ and at $90 \mathrm{~km}$ is shown in Fig. 6. The $20 \mathrm{~km}$ surface dissects the ozone layer at mid-latitudes and shows the winter-spring ozone maxima but lies below the ozone layer at the equator. The $90 \mathrm{~km}$ surface is inside the second ozone layer at all latitudes. During the equinox times the second ozone maximum appears at all latitudes, other times it is concentrated more above the winter pole.

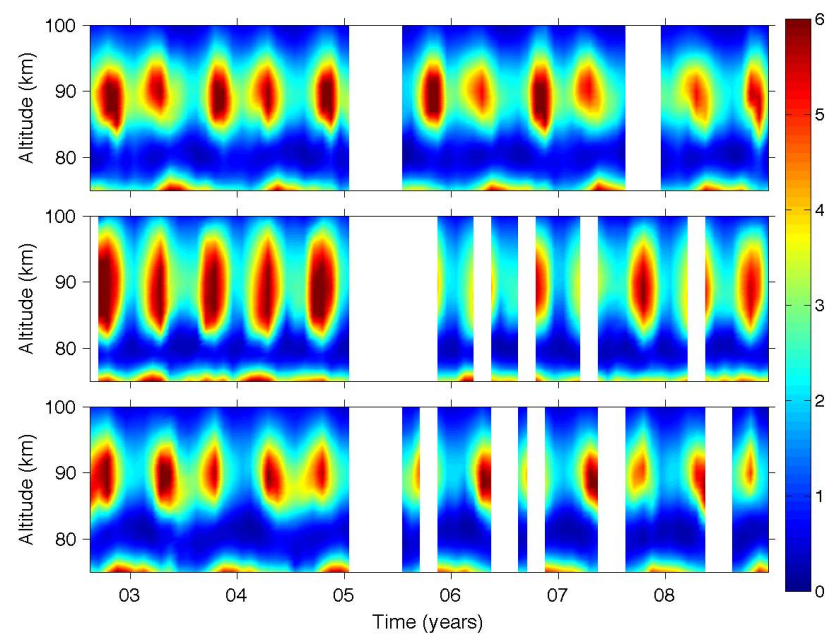

Fig. 5. Monthly ozone number density in the MLT in three latitude belts as a function of time and altitude. The density is scaled by $10^{8} \mathrm{~cm}^{-3}$. The time covered is 1 August 2002-31 December 2008. Latitude belts: $30^{\circ} \mathrm{N}-50^{\circ} \mathrm{N}$ (top), $10^{\circ} \mathrm{S}-10^{\circ} \mathrm{N}$ (middle), $30^{\circ} \mathrm{S}-$ $50^{\circ} \mathrm{S}$ (bottom).

In Fig. 7 we have shown the relative variability of the ozone monthly time series as a function of time and altitude in three latitude belts. We have subtracted the variability of the estimated retrieval errors of GOMOS data. Below $20 \mathrm{~km}$ the variability is high but otherwise the overall variability in the stratosphere is low. The median over latitudes and times in the stratosphere is $5.5 \%$ (the same average for retrieval errors is $0.6 \%$ ). Somewhat higher variability appears at midlatitudes during the winter times. In the MLT a very high variability can be seen around the ozone minimum $75-85 \mathrm{~km}$ and reduced variability around the ozone maximum at $90 \mathrm{~km}$. The median over latitudes and times in the MLT is 19\% (the same average for retrieval errors is $1 \%$ ).

How does the diurnal variation of ozone affect these results? In Fig. 8 we have shown the diurnal variation of ozone at three altitudes as estimated from the NCAR ROSE model (see also SABER results in Huang et al., 2008). The diurnal variation can safely be ignored in the stratosphere but not in the MLT. The diurnal variation affects the variability through the local hour sampling distributions shown in Fig. 2. The variability caused by these distributions is $2-4 \%$ at $90 \mathrm{~km}$. The difference in the mean of the two sampling distributions is below $3 \%$ at $90 \mathrm{~km}$.

In order to get a more quantitative view into the systematic variations of the ozone distribution in time, we have carried out a time series analysis of the ozone number density profiles in the latitude range $50^{\circ} \mathrm{S}-50^{\circ} \mathrm{N}$. The latitudinal limits are such that there are no seasonal gaps in data (as would be in polar areas). Figure 9 shows an example of the time series fitting to the ozone number density data at $90 \mathrm{~km}$ in the latitudinal belt $40^{\circ} \mathrm{N}-50^{\circ} \mathrm{N}$. The figure also includes the corresponding fit residual and the individual fitting components. 

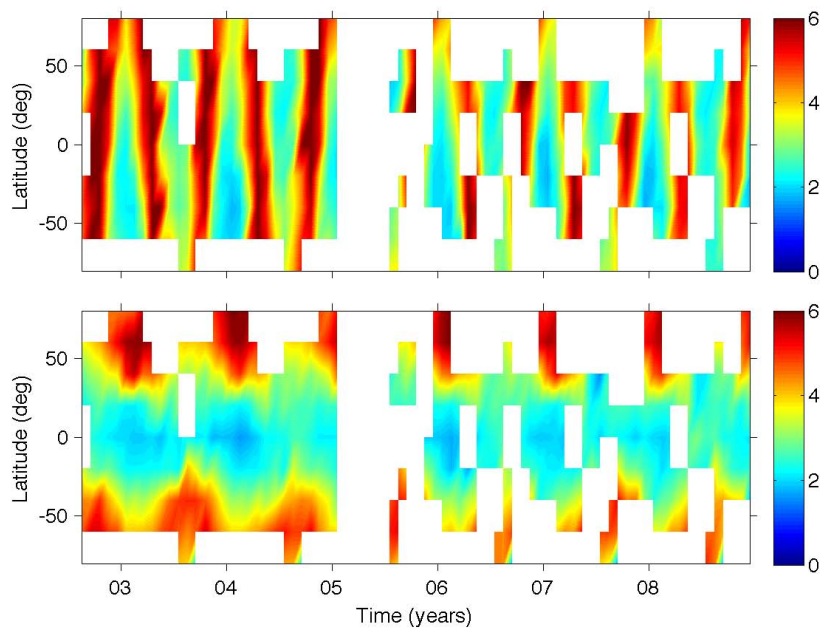

Fig. 6. Monthly ozone number density at $90 \mathrm{~km}$ (upper panel, scaled by $10^{8} \mathrm{~cm}^{-3}$ ) and $20 \mathrm{~km}$ (lower panel, scaled by $10^{12} \mathrm{~cm}^{-3}$ ) as a function of time and latitude in 1 August 2002-31 December 2008.

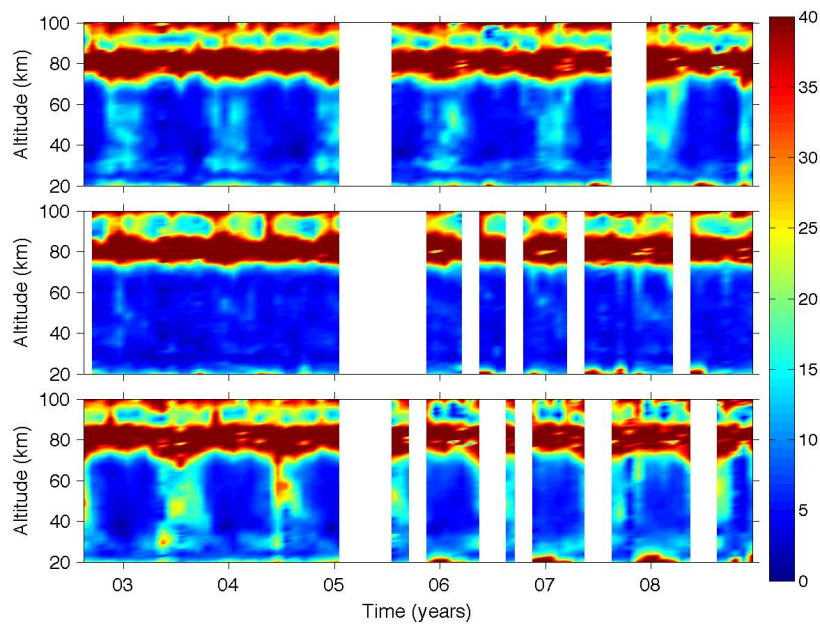

Fig. 7. Monthly ozone variability in $15-100 \mathrm{~km}$ in three latitude belts as a function of time and altitude. The variability shown is the quartile distance of data subtracted by the quartile distance of the retrieval errors (the factor $1 / 1.349$ of Eq. (1) included). The values are relative to the median values and in $\%$. Latitude belts: $30^{\circ} \mathrm{N}-$ $50^{\circ} \mathrm{N}$ (top), $10^{\circ} \mathrm{S}-10^{\circ} \mathrm{N}$ (middle), $30^{\circ} \mathrm{S}-50^{\circ} \mathrm{S}$ (bottom).

The solar, QBO and harmonic terms are in relative units with respect to the constant term (not shown in this figure). Figure 9 shows that the fit at $90 \mathrm{~km}$ is able to follow reasonably well the large semi-annual oscillation of ozone and it also shows a declining mean ozone content from the solar term in the MLT. The fit fails to replicate the high ozone values seen above the sinusoidal maxima (for high values of ozone in the MLT, see Smith et al., 2008).

The constant term profiles ( $c(z)$ in Eq. 2) at different latitudes are shown in Fig. 10 and Fig. 11. The constant term has a low median fitting uncertainty of $0.16 \%$. The profiles

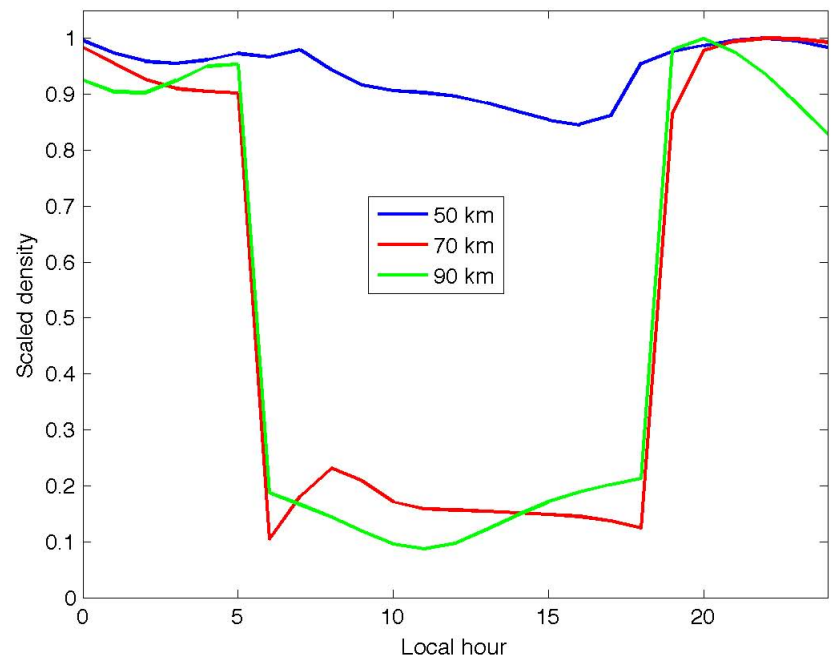

Fig. 8. Ozone number density as a function of the local time at three altitudes. Densities are calculated using the NCAR ROSE model in $5^{\circ} \mathrm{S}-5^{\circ} \mathrm{N}$. The number densities are scaled by the maximum values reached at a given altitude.
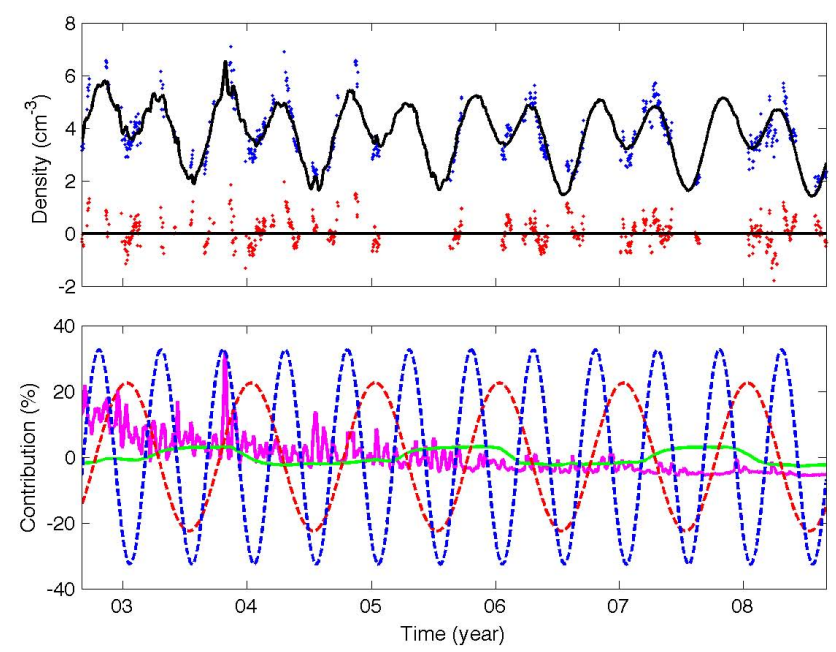

Fig. 9. An example of the $\mathrm{O}_{3}$ number density fitting at $90 \mathrm{~km}$ in $40^{\circ} \mathrm{N}-50^{\circ} \mathrm{N}$. Time axis unit is day. In the upper panel GOMOS measurements are shown by the blue dots and the fit by the black line. The residual is shown by red dots. All three scaled by scaled by $10^{8} \mathrm{~cm}^{-3}$. In the lower panel the identifications are: Annual ( $a_{1}$ and $b_{1}$ contributions): dashed red, Semi-annual ( $a_{2}$ and $b_{2}$ contributions): dashed blue, QBO 1 ( $q_{1}$ and $q_{2}$ contributions): solid green, solar $(s)$ : solid magenta. The components have been scaled by a constant coefficient and given in $\%$. The constant term itself has not been shown.

show the stratospheric main ozone layer and the secondary ozone layer in the MLT. Besides the two maxima, the deep ozone minimum around $80 \mathrm{~km}$ is noteworthy. The stratospheric and MLT contributions are nearly symmetric with respect to the equator. The main peak altitude is latitude 

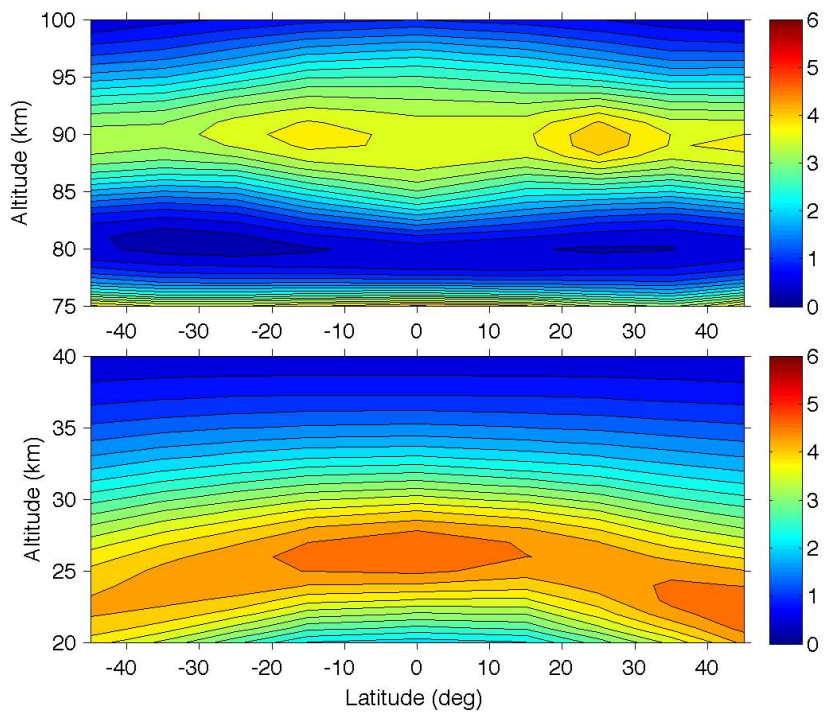

Fig. 10. The constant factor $\mathrm{c}(\mathrm{z})$ in the $\mathrm{O}_{3}$ time series as a function of latitude and altitude. Upper panel: MLT with the scale $10^{8} \mathrm{~cm}^{-3}$. Lower panel: Stratosphere with the scale $10^{12} \mathrm{~cm}^{-3}$.

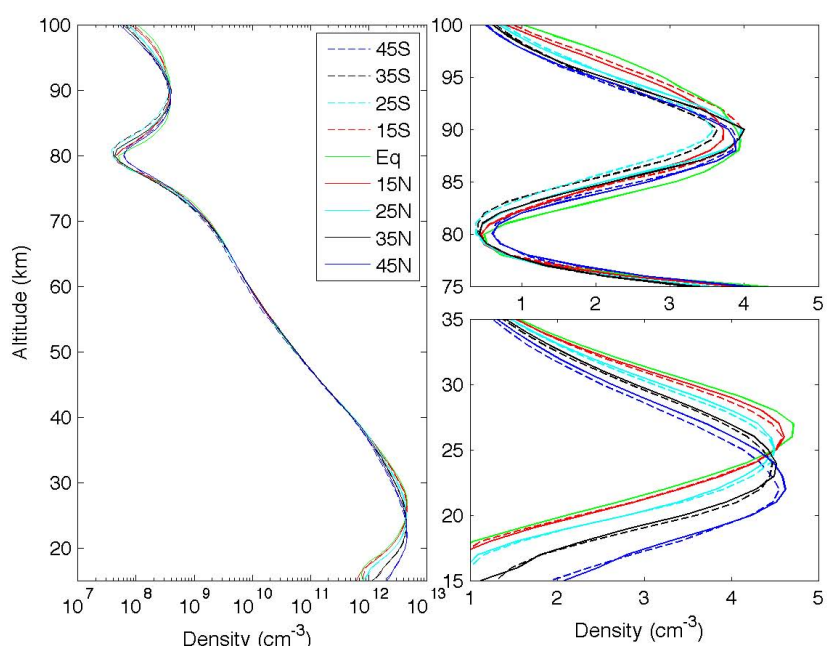

Fig. 11. The $\mathrm{O}_{3}$ constant factor $c(z)$ as a function of altitude for several latitude belts. The panel in left shows constant profiles 15$100 \mathrm{~km}$ at different latitudes. The upper right panel shows the same profiles in the MLT (values scaled by $10^{8}$ ) and the lower right panel in the stratosphere (values scaled by $10^{12}$ ).

dependent whereas the MLT structure (minimum and the second maximum) is almost independent of latitude. If we calculate the total ozone from the constant term in the range 15$100 \mathrm{~km}$ the ozone column is 244 Dobson units in the equator, 264 Dobson units in south mid-latitudes and 271 Dobson units in north mid-latitudes.

The annual, semi-annual, QBO and solar amplitudes for the stratosphere are shown in Fig. 12 and for the MLT in Fig. 13. The relative uncertainties of the harmonic compo-
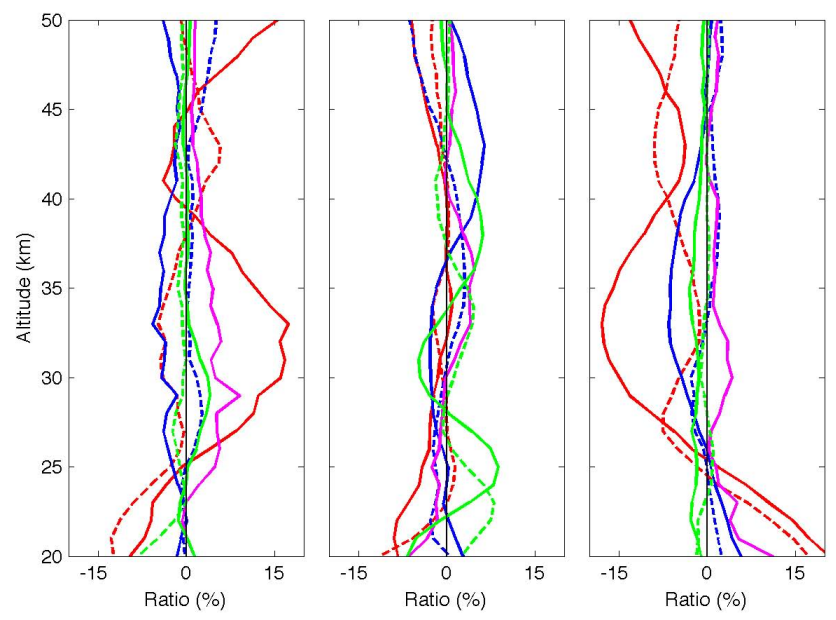

Fig. 12. Fitting components for ozone as a function of altitude in three latitude belts in the stratosphere. All amplitudes have been given as a ratio between the original amplitude in Eq. (2) and the the constant term $c(z)$ in Eq. (2) and given in \%. Line identifications: annual $\left(a_{1}\right.$ and $\left.b_{1}\right)$ : solid and dashed red, respectively, Semi-annual ( $a_{2}$ and $\left.b_{2}\right)$ : solid and dashed blue, respectively, QBO $10 \mathrm{hPa}\left(q_{1}\right)$ and $30 \mathrm{hPa}\left(q_{2}\right)$ : solid and dashed green, respectively, solar $(s)$ : solid magenta. The zero value line has been shown by a thin black line. Left: $50^{\circ} \mathrm{S}-40^{\circ} \mathrm{S}$, Middle: $10^{\circ} \mathrm{S}-10^{\circ} \mathrm{N}$, Right: $40^{\circ} \mathrm{N}-50^{\circ} \mathrm{N}$.

nents vary considerably as a function of altitude. The median (over latitudes $50^{\circ} \mathrm{S}-50^{\circ} \mathrm{N}$ and altitudes $20-100 \mathrm{~km}$ ) uncertainty values are in the range $5-15 \%$. The annual amplitudes $\left(a_{1}\right.$ and $\left.b_{1}\right)$ dominate over the semi-annual ones $\left(a_{2}\right.$ and $\left.b_{2}\right)$. Below $25 \mathrm{~km}$ the annual amplitude increases (absolute value) at all latitudes towards the tropopause. At the equator the increase takes place below the ozone layer but at mid-latitudes it is inside the ozone layer. The two components $\left(a_{1}\right.$ and $\left.b_{1}\right)$ have the same sign and this leads to the winter maxima of ozone in both hemispheres. The amplitude is larger at northern than at southern latitudes. The second increase of the annual amplitude $a_{1}$ takes place at mid-latitudes in $30-35 \mathrm{~km}$ giving rise a summer maximum. There is an interesting deep minimum at mid-latitudes in the annual oscillation around $25 \mathrm{~km}$.

In the MLT below $70 \mathrm{~km}$ the first $\left(a_{1}\right)$ annual term dominates at mid-latitudes all other amplitudes being small. The annual amplitude (absolute value) reaches $75 \%$ in south and $50 \%$ in north at $75 \mathrm{~km}$. Notice that these amplitudes have opposite signs when compared to the annual amplitudes in the ozone layer below $25 \mathrm{~km}$. They lead to summer maxima. The signs are changed again when the mid-latitude annual terms go through zero at $80 \mathrm{~km}$ and reaches new maxima of $85 \%$ (south) and $60 \%$ (north) around $83 \mathrm{~km}$. The semiannual amplitudes start to increase after $75 \mathrm{~km}$ at all latitudes. In the equator the first semi-annual component $\left(a_{2}\right)$ rapidly increases up to $85 \%$ at $82 \mathrm{~km}$ and then slowly decreases at higher altitudes. At $90 \mathrm{~km}$ it is $50 \%$ and dominates over other 

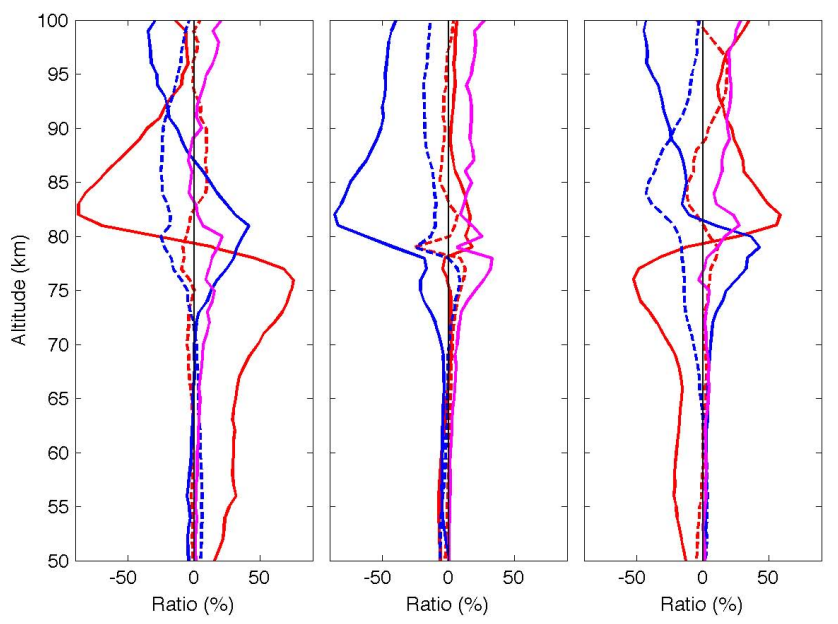

Fig. 13. Fitting components as a function of altitude in three latitude belts in the MLT. All amplitudes have been given as a ratio between the original amplitude in Eq. (2) and the the constant term $c(z)$ in Eq. (2) and given in \%. Line identifications: Annual $\left(a_{1}\right.$ and $\left.b_{1}\right)$ : solid and dashed red, respectively. Semi-annual $\left(a_{2}\right.$ and $\left.b_{2}\right)$ : solid and dashed blue, respectively, solar $(s)$ : solid magenta. The QBO values are not shown. The zero value line has been shown by a thin black line. Left: $50^{\circ} \mathrm{S}-40^{\circ} \mathrm{S}$, Middle: $10^{\circ} \mathrm{S}-10^{\circ} \mathrm{N}$, Right: $40^{\circ} \mathrm{N}-$ $50^{\circ} \mathrm{N}$.

amplitudes. This gives maximum ozone density in the beginning of April and October. At mid-latitudes around the second maximum the annual and semi-annual amplitudes have nearly the same (absolute) value. The density shows a mix of annual and semi-annual cycles. An example was shown in Fig. 9.

The minor components of the time series are the solar and QBO terms. We have studied changes in the $R^{2}$-values for the fitting time series Eq. (2) where solar, QBO or both are eliminated. In the equatorial area up to $40 \mathrm{~km}$ the two QBO terms considerably improve the quality of the fitting. The solar term improves the fits only in the MLT above $85 \mathrm{~km}$ (equator and north) and above $90 \mathrm{~km}$ (south). Everywhere else the solar and QBO contributions to the fits are small.

In the equatorial stratosphere QBO terms have relatively large values of $8-9 \%$ between 20 and $40 \mathrm{~km}$. The median uncertainty (over altitudes) of the QBO terms is $3.5 \%$. The QBO shows two cell structure with maxima around $25 \mathrm{~km}$ and $38 \mathrm{~km}$. In the MLT the solar term grows with altitude reaching $20-25 \%$ at $100 \mathrm{~km}$ with the median relative uncertainty of $8-10 \%$ above $85 \mathrm{~km}$. At the second ozone maximum the solar contribution is almost zero in the SH but 17$19 \%$ at the equator and northern mid-latitudes.

The fit for the ozone times series is defined for all times during the 6 years period, for all latitudes $50^{\circ} \mathrm{S}-50^{\circ} \mathrm{N}$ and for all altitudes $15-100 \mathrm{~km}$. Therefore, it is possible to calculate various vertical column distributions. Fig. 14 shows the ozone columns in $15-100 \mathrm{~km}$ and in $80-100 \mathrm{~km}$. The "total" column shows clearly the mid-latitude ozone winter-

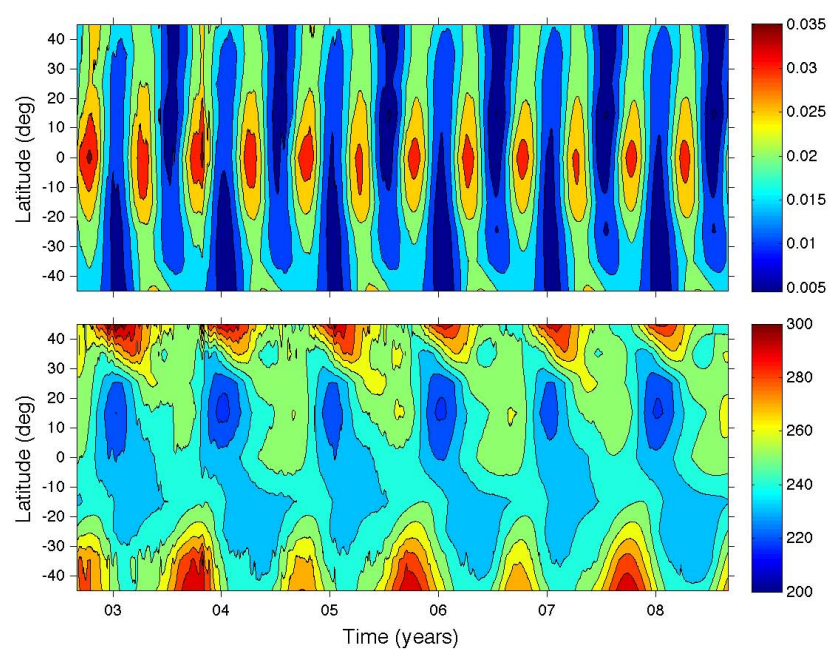

Fig. 14. The daily vertical partial ozone columns as a function of time and latitude. The columns are calculated from the time series. The upper panel gives the partial column in $80-100 \mathrm{~km}$ and the lower panel the partial column in $15-100 \mathrm{~km}$. The unit in both figures is Dobson unit $\left(2.69 \times 10^{16}\right.$ molecules $\left.\mathrm{cm}^{-2}\right)$.

spring maxima and low ozone values in the equator. The lowest values in this altitude limited column distribution are seen around $15^{\circ} \mathrm{N}$ during winter. In the MLT the semiannual variation prevails everywhere with largest columns at the equator. The overall structure replicates the zigzag pattern already seen in Fig. 6. The equatorial ozone in the MLT shows a decreasing trend.

The results obtained above can be compared with the earlier results in literature. The limitation of the present data set to the declining part of the very peculiar solar cycle 23 must be remembered when results are compared with time series covering several solar cycles. Results about the annual and semi-annual cycles are hard to find as the time series are usually deseasonalized before the regression analysis. In Perliski et al. (1989) the authors show annual and semi-annual amplitudes in the stratosphere based on SBUV 1978-1987 measurements and a two-dimensional photochemical model. The corresponding amplitudes (of mixing ratios) from GOMOS and SBUV are quite similar.

The physical and chemical processes behind the stratospheric variations of ozone are discussed in detail in Perliski et al. (1989) and in Ko et al. (1989) and summarised in Brasseur and Solomon (2005) and in Dessler (2000). The explanation for the strong semiannual signal in the MLT has been sought from the semi-annual change of the pole-to-pole meridional circulation and from the semi-annual variation of the diurnal tide (see Smith (2004) and references therein). The former affects the $\mathrm{H}_{2} \mathrm{O}$ amount and therefore the catalytic reactions of hydrogen with ozone. The solar tide affects O-related ozone chemistry (production and loss) and temperature. In the stratosphere and MLT the chemical modelling predicts anticorrelation of temperature and ozone. 

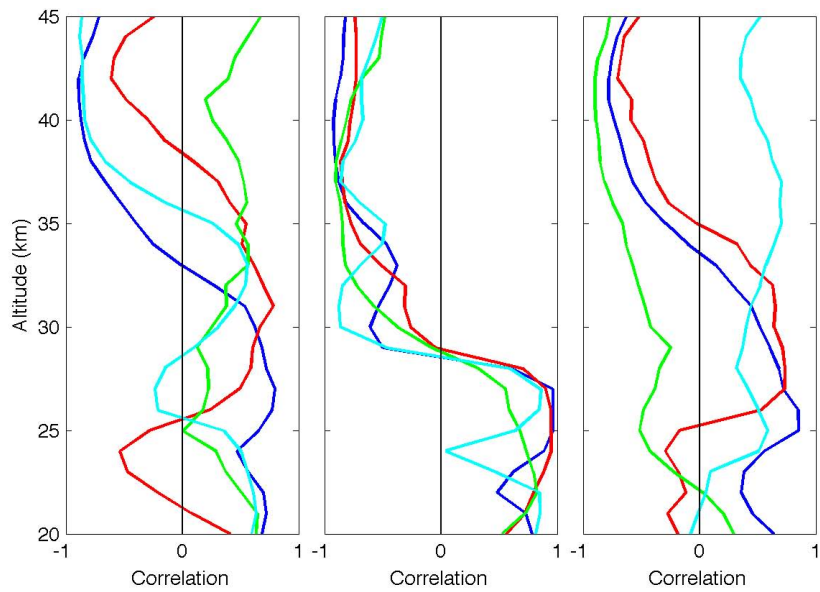

Fig. 15. Correlations of the monthly ozone median densities with the monthly median temperatures (from ECMWF) as a function of altitude. Left: $30^{\circ} \mathrm{S}-50^{\circ} \mathrm{S}$, Middle: $10^{\circ} \mathrm{S}-10^{\circ} \mathrm{N}$, Right: $30^{\circ} \mathrm{N}-$ $50^{\circ} \mathrm{N}$. Line identifications: DJF: blue, MAM: red, JJA: green, SON: cyan.

The correlation of GOMOS monthly ozone and monthly temperature (from ECMWF) in the stratosphere is shown in Fig. 15 for four seasons and three latitude regions. In the equatorial region the correlation is for all seasons positive below $30 \mathrm{~km}$ and changes then to negative. This change can be understood as the transition from the region of dynamical control to the region of chemical control (see Brasseur and Solomon, 2005). Mid-latitude correlations show similar transitions but not in so uniform way.

There are many studies on solar cycle effects on stratospheric ozone profiles. Reviews of the results can be found in Harris et al. (1999) and in WMO (2007). In our quite a short data set it was not possible to extract the solar response in the stratosphere. Using longer satellite data series the solar effect has been successfully retrieved in Randel and $\mathrm{Wu}$ (2007); Soukharev and Hood (2006); Jones et al. (2009). In the MLT the solar cycle has been estimated only by various model simulations. In Marsh et al. (2007) the WACCM3 simulations indicate $50 \%$ increase in the ozone mixing ratio from the solar minimum to the solar maximum. In our case the changes in number densities at the second maximum are at most $20 \%$.

Many studies have dealt with QBO effects in stratospheric ozone profiles. Reviews of the results can be found in Harris et al. (1999) and in WMO (2007). GOMOS results agree about the two cell structure in the equatorial stratosphere discussed, for example, in Randel and Wu (2007).

\section{$5 \quad \mathrm{NO}_{2}$}

The nighttime distribution of $\mathrm{NO}_{2}$ from GOMOS measurements is shown in Fig. 16. A clear annual cycle is visible at

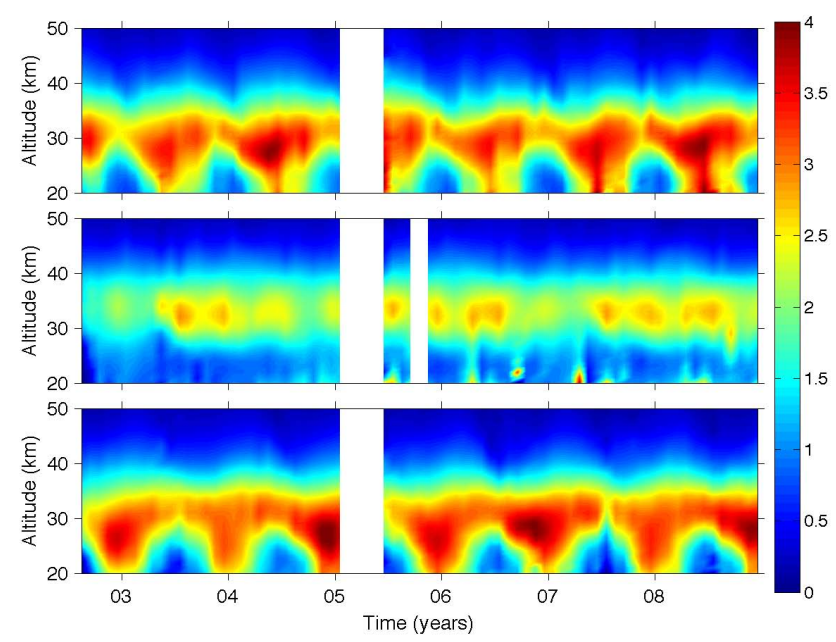

Fig. 16. Monthly $\mathrm{NO}_{2}$ number density in the stratosphere in three latitude belts in 2002-2008 as a function of time and altitude. The density is scaled by $10^{9} \mathrm{~cm}^{-3}$. The time covered is 1 August 2002 31 December 2008. Latitude belts: $30^{\circ} \mathrm{N}-50^{\circ} \mathrm{N}$ (top), $10^{\circ} \mathrm{S}-$ $10^{\circ} \mathrm{N}$ (middle), $30^{\circ} \mathrm{S}-50^{\circ} \mathrm{S}$ (bottom).

mid-latitudes. The " $\mathrm{NO}_{2}$ layer" around $30 \mathrm{~km}$ starts to expand in early winter mainly towards the tropopause but also in a lesser amount to higher altitudes. The maximum extent is reached during midsummer. After the maximum the layer contracts from the lower side while the upper boundary still increases. The minimum of the layer is reached in late fall. In the equatorial band a weak semi-annual cycle prevails. The variability of the $\mathrm{NO}_{2}$ distribution (not shown) is around $20 \%$ at the maximum $30 \mathrm{~km}$. The median over latitudes and times in the stratosphere is $25 \%$ (the same average for retrieval errors is $13 \%$ ). The diurnal variation of $\mathrm{NO}_{2}$ and $\mathrm{NO}_{3}$ from the NCAR ROSE model is shown in Fig. 17. The variability due to the diurnal variation is $3-6 \%$. The difference in the mean of the two sampling distributions is below $4 \%$.

In Fig. 18 we show an example of the time series fitting in the $40^{\circ} \mathrm{N}-50^{\circ} \mathrm{N}$ latitude band at $30 \mathrm{~km}$. In this case GOMOS data are reasonably well fitted with the annual term dominating.

The constant term in Figs. 19 and 20 shows a robust distribution around $30 \mathrm{~km}$. The median fitting uncertainty is $0.4 \%$. The maximum values are reached at mid-latitudes. The overall distribution is quite symmetric with respect to the equator. The partial column $20-50 \mathrm{~km}$ from the constant term peaks at mid-latitudes with $5.3 \times 10^{15} \mathrm{~cm}^{-2}$ in south and $5.2 \times 10^{15} \mathrm{~cm}^{-2}$ in north. The equator column is $3.9 \times 10^{15} \mathrm{~cm}^{-2}$.

The fitting components are shown in Fig. 21. At midlatitudes the annual amplitude $\left(a_{1}\right)$ is around $10-15 \%$ at the maximum $(30 \mathrm{~km})$ and grows to $60-80 \%$ below the maximum. The annual variation has been analysed from the chemistry and dynamics viewpoints in Bracher et al. (2005) and Brohede et al. (2007). At the equator the largest 


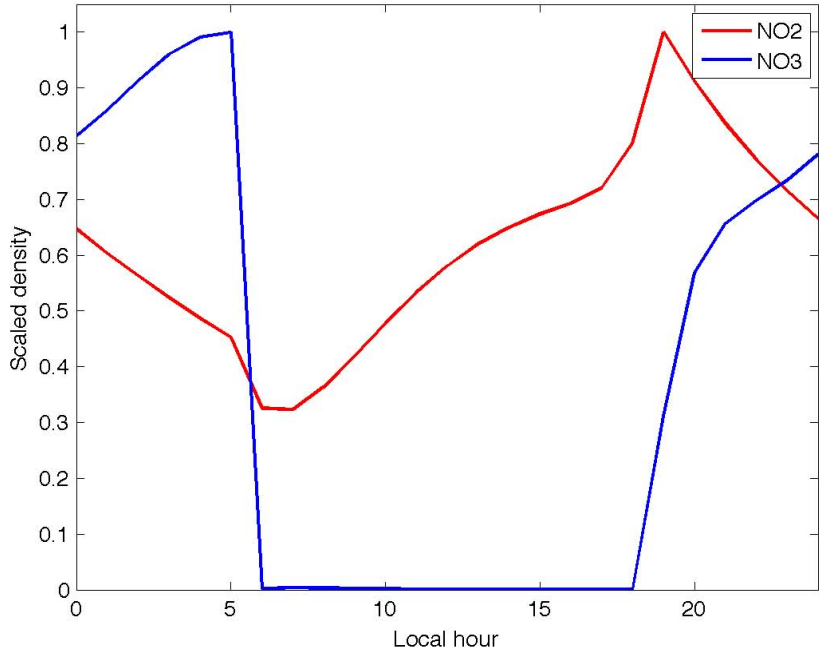

Fig. 17. $\mathrm{NO}_{2}$ number density vs. local time at $30 \mathrm{~km}$ and $\mathrm{NO}_{3}$ number density vs local time at $40 \mathrm{~km}$. The number densities are scaled by the maximum values reached at a given altitude. Results are from the NCAR ROSE model in $5^{\circ} \mathrm{S}-5^{\circ} \mathrm{N}$.
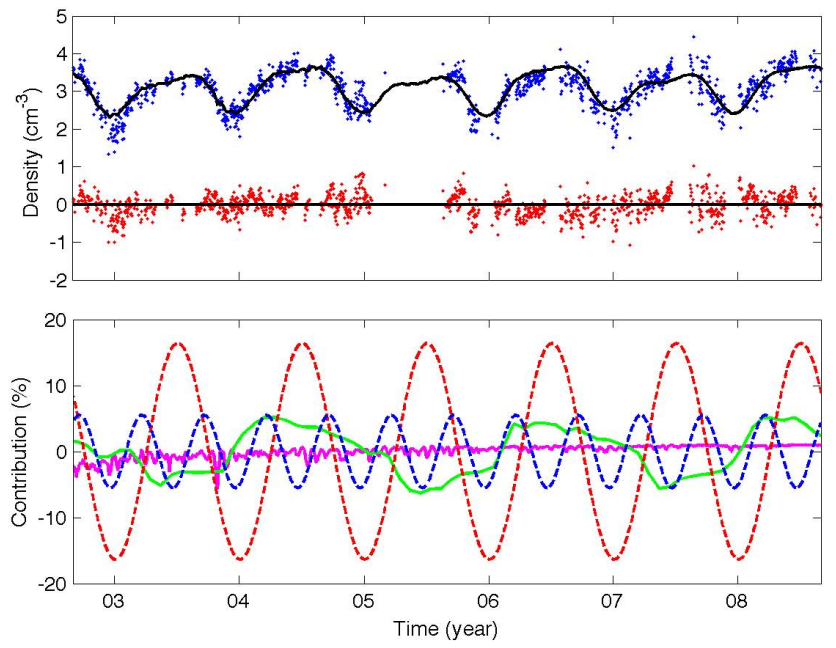

Fig. 18. An example of the $\mathrm{NO}_{2}$ number density fitting at $30 \mathrm{~km}$ in the $40^{\circ} \mathrm{N}-50^{\circ} \mathrm{N}$ latitude band. Time axis unit is day. In the upper panel GOMOS measurements are shown by the blue dots and the fit by the black line. The residual is shown by red dots. All three scaled by scaled by $10^{9} \mathrm{~cm}^{-3}$. In the lower panel the identifications are: annual ( $a_{1}$ and $b_{1}$ contributions): dashed red, Semi-annual ( $a_{2}$ and $b_{2}$ contributions): dashed blue, QBO 1 ( $q_{1}$ and $q_{2}$ contributions): solid green, solar $(s)$ : solid magenta. The components have been scaled by a constant coefficient and given in $\%$. The constant term itself has not been shown.

harmonic is semi-annual term $\left(a_{2}\right)$ with the amplitude of $6 \%$. The median uncertainty of the harmonics varies $4-12 \%$.

Both the solar and QBO term improve the quality of the $\mathrm{NO}_{2}$ fits. The median uncertainties for solar and QBO are in the range of $14-21 \%$. The QBO has a similar nodal structure at the equator as ozone had. The maximum amplitude of

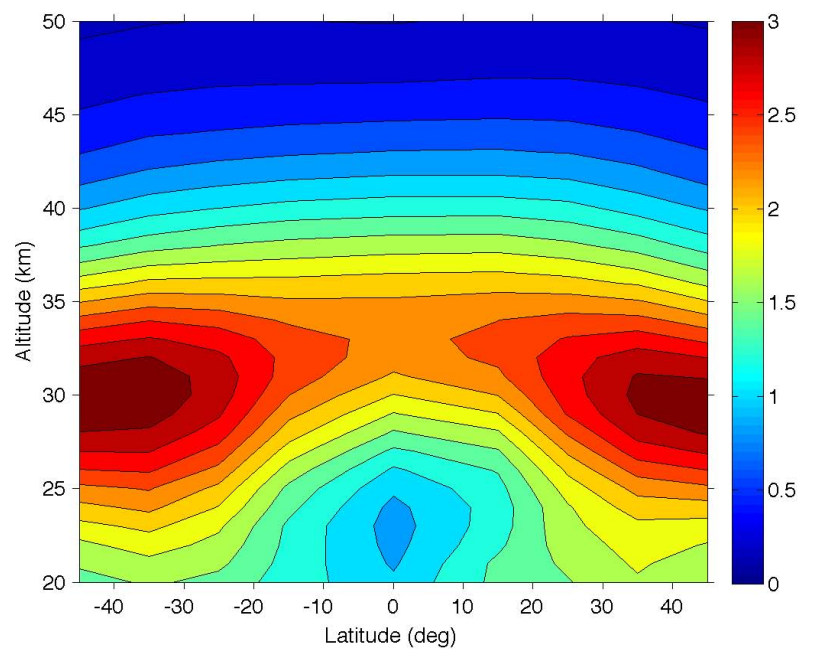

Fig. 19. The constant factor $c(z)$ in the $\mathrm{NO}_{2}$ time series as a function of latitude and altitude. The scale is $10^{9} \mathrm{~cm}^{-3}$.

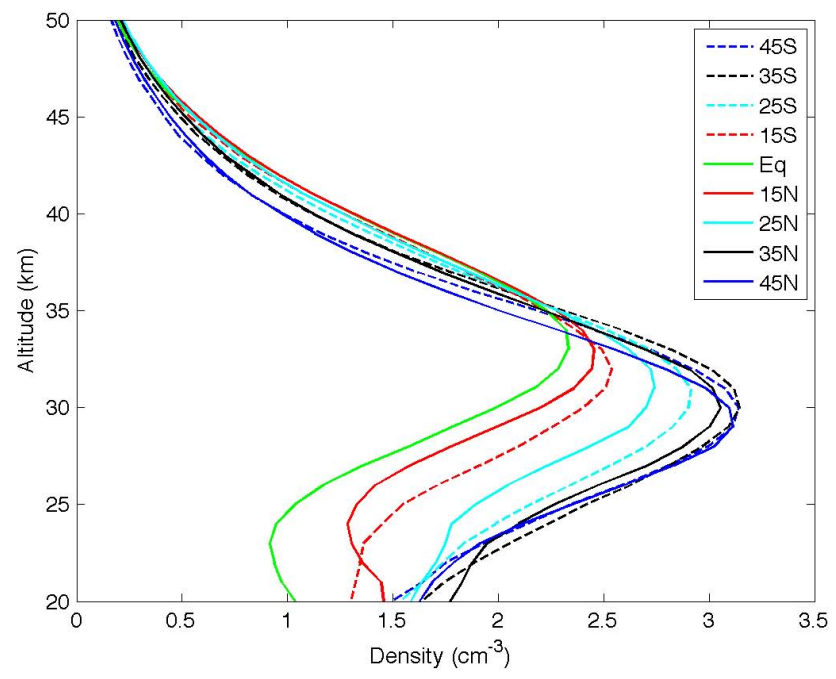

Fig. 20. The $\mathrm{NO}_{2}$ constant factor profiles $c(z)$ as a function of altitude for several latitude belts. The profile values are scaled by $10^{9}$.

the $\mathrm{QBO}$ is $18 \%$ at the equator around the $\mathrm{NO}_{2}$ maximum. $\mathrm{A}$ second, smaller peak can be found at $43 \mathrm{~km}$. At mid-latitudes the QBO impact is small. The solar term at the equator shows negative values (i.e. more $\mathrm{NO}_{2}$ during the solar minimum) in $25-40 \mathrm{~km} 10 \%$. At southern and northern latitudes negative values are also seen below $35 \mathrm{~km}$. In south and at the equator the solar term is small in the upper stratosphere but at the northern latitudes the solar term grows to $30 \%$ in the upper stratosphere. In Hood and Soukharev (2006) authors analyse $\mathrm{NO}_{x}$ content at altitudes $32-53 \mathrm{~km}$ using HALOE results in 1991-2003. They found in the equatorial region negative values of $10 \%$ around $35 \mathrm{~km}$ and $20 \%$ around $50 \mathrm{~km}$. GOMOS results agree with the first finding but do not show the large solar impact in the upper equatorial stratosphere. 

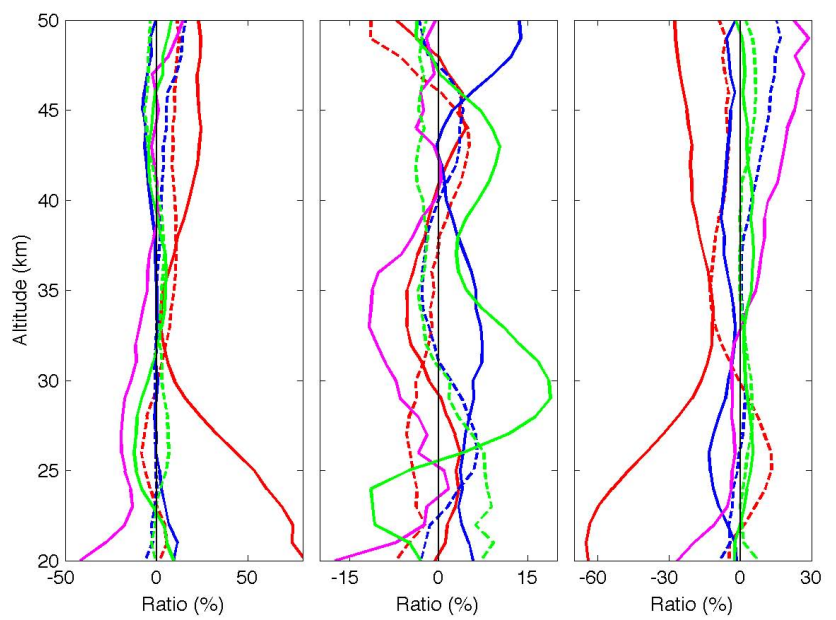

Fig. 21. $\mathrm{NO}_{2}$ fitting components as a function of altitude in three latitude belts in the stratosphere. All amplitudes have been given as a ratio between the original amplitude in Eq. (2) and the the constant term $c(z)$ in Eq. (2) and given in \%. Line identifications: Annual $\left(a_{1}\right.$ and $\left.b_{1}\right)$ : solid and dashed red, respectively, Semi-annual $\left(a_{2}\right.$ and $\left.b_{2}\right)$ : solid and dashed blue, respectively, QBO $10 \mathrm{hPa}\left(q_{1}\right)$ and $30 \mathrm{hPa}\left(q_{2}\right)$ : solid and dashed green, respectively, solar $(s)$ : solid magenta. The zero value line has been shown by a thin black line. Left: $50^{\circ} \mathrm{S}-40^{\circ} \mathrm{S}$, Middle: $10^{\circ} \mathrm{S}-10^{\circ} \mathrm{N}$, Right: $40^{\circ} \mathrm{N}-50^{\circ} \mathrm{N}$. Note that the $\mathrm{x}$-axis ranges vary in panels.

Figure 22 shows the $\mathrm{NO}_{2}$ total column in $20-50 \mathrm{~km}$. Clear annual summer maxima at mid-latitudes and minimum values in the equatorial region. The maximum regions seem to be slightly inclined on the time-latitude plane with the maximum delayed towards higher latitudes.

\section{$6 \quad \mathrm{NO}_{3}$}

The number density distribution of GOMOS $\mathrm{NO}_{3}$ measurements is shown in Fig. 23. The " $\mathrm{NO}_{3}$ layer" shows a remarkable extent in vertical with the maximum at $40 \mathrm{~km}$. At the mid-latitudes a clear annual cycle is evident with a clear asymmetry between southern and northern latitudes. The maxima seem to appear at the same time through the layer. The equatorial $\mathrm{NO}_{3}$ shows a semi-annual cycle with maxima at the equinox times. The maxima have more variation than the ones at mid-latitudes. The variability of the $\mathrm{NO}_{3}$ distribution (not shown) is around $30 \%$ at $40 \mathrm{~km}$. The median variability over latitudes and times in the stratosphere is $56 \%$ (the same average for retrieval errors is $36 \%$ ). The diurnal variation of $\mathrm{NO}_{3}$ is shown in Fig. 17. The variability due to the diurnal variation is $2-4 \%$. The difference in the mean of the two sampling distributions is below $3 \%$.

Figure 24 shows a fitting example at $40 \mathrm{~km}$ (the number density maximum) at the southern mid-latitudes $40^{\circ} \mathrm{S}-50^{\circ} \mathrm{S}$. The variation at these latitudes can be explained to a large part by the annual term. The solar and QBO terms are very small.

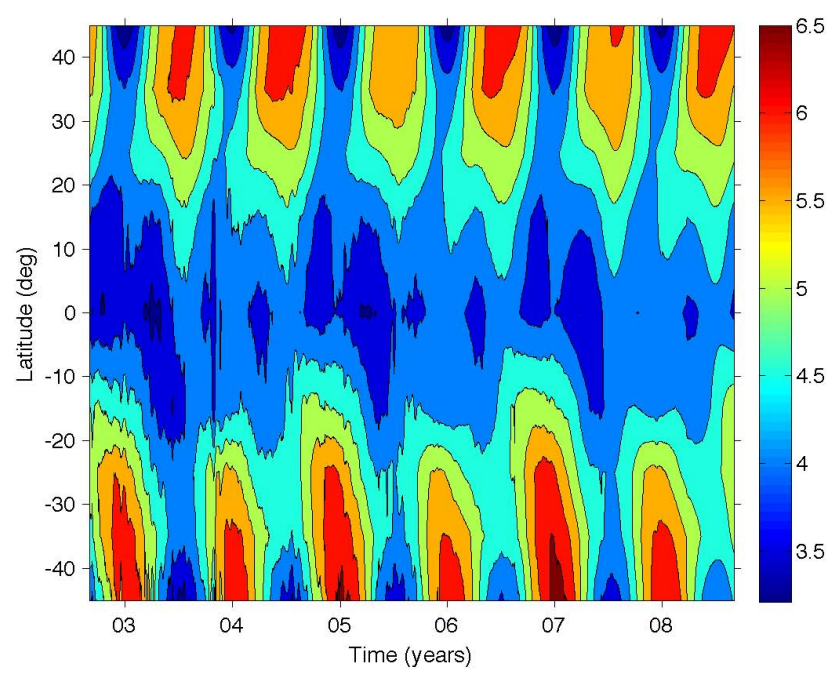

Fig. 22. The daily vertical partial $\mathrm{NO}_{2}$ column in $20-50 \mathrm{~km}$ as a function of time and latitude. The column is calculated from the time series and scaled by $10^{15}$ molecules $\mathrm{cm}^{-2}$.

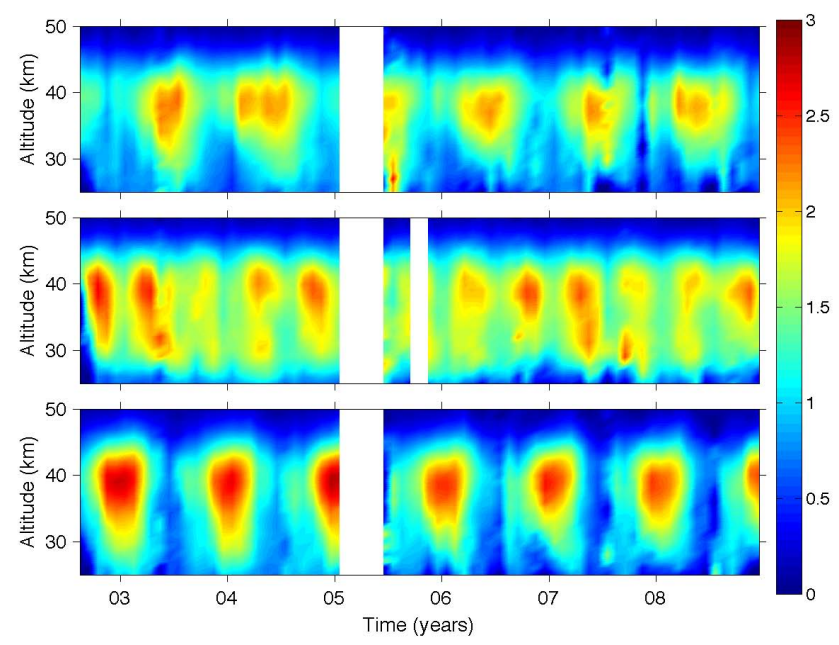

Fig. 23. Monthly $\mathrm{NO}_{3}$ number density in the stratosphere in three latitude belts in 2002-2008 as a function of time and altitude. The density is scaled by $10^{7} \mathrm{~cm}^{-3}$. The time covered is 1 August 200231 December 2008. Latitude belts: $30^{\circ} \mathrm{N}-50^{\circ} \mathrm{N}$ (top), $10^{\circ} \mathrm{S}-$ $10^{\circ} \mathrm{N}$ (middle), $30^{\circ} \mathrm{S}-50^{\circ} \mathrm{S}$ (bottom).

The latitude distribution and profiles of the constant term are shown in Fig. 25 and Fig. 26. The median fitting uncertainty is $0.6 \%$. The constant term shows a remarkable anvil shape with a large latitudinal extent at the maximum density region around $40 \mathrm{~km}$ and a deep vertical extent around the equator. The distribution is nearly symmetric with respect to the equator. The total column from the constant term $25-$ $50 \mathrm{~km}$ peaks in the equator with the column $34 \times 10^{12} \mathrm{~cm}^{-2}$. At southern mid-latitudes the column is $26 \times 10^{12} \mathrm{~cm}^{-2}$ and at northern mid-latitudes $25 \times 10^{12} \mathrm{~cm}^{-2}$. 

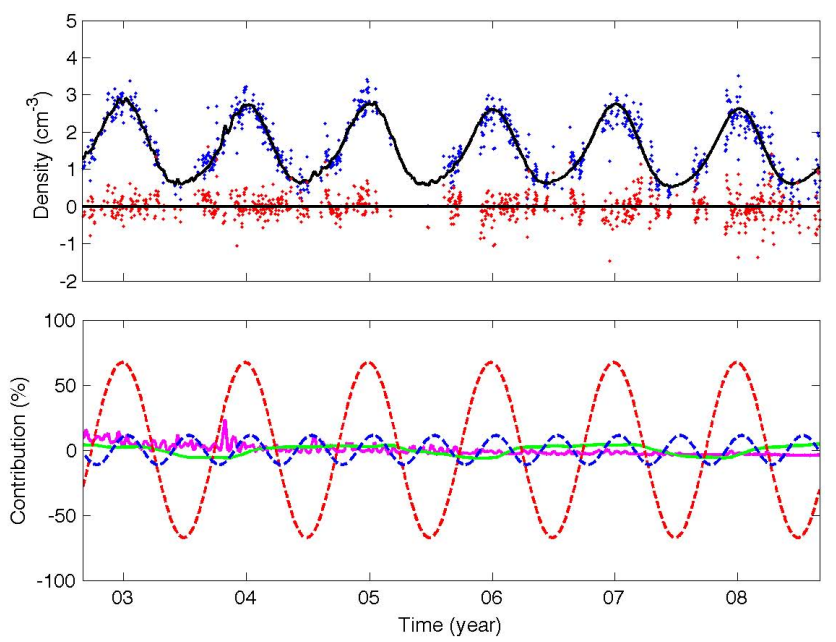

Fig. 24. An example of the $\mathrm{NO}_{3}$ number density fitting at $40 \mathrm{~km}$ in $40^{\circ} \mathrm{S}-50^{\circ} \mathrm{S}$. Time axis unit is day. In the upper panel GOMOS measurements are shown by the blue dots and the fit by the black line. The residual is shown by red dots. All three scaled by scaled by $10^{7} \mathrm{~cm}^{-3}$. In the lower panel the identifications are: Annual ( $a_{1}$ and $b_{1}$ contributions): dashed red, Semi-annual ( $a_{2}$ and $b_{2}$ contributions): dashed blue, QBO 1 ( $q_{1}$ and $q_{2}$ contributions): solid green, solar $(s)$ : solid magenta. The components have been scaled by a constant coefficient and given in $\%$. The constant term itself has not been shown.

The other time series coefficients are shown in Fig. 27. The annual term $\left(a_{1}\right)$ dominates strongly the time evolution outside the equatorial region with the maximum amplitude of $60 \%$ in south and $40 \%$ in north. In the equatorial region the semi-annual amplitude is around $15 \%$ dominating the variation. The median uncertainties of the harmonic components are 6-20\%. The inclusion of the QBO improves the fit only in the equatorial region and has at the $\mathrm{NO}_{3}$ maximum $10 \%$ amplitude. The solar term does not make difference in the fit even if the contributions in Fig. 27 are large. The median estimated uncertainty for the solar term is $30 \%$ and for the QBO 27-54\%.

Figure 28 shows the total $\mathrm{NO}_{3}$ column in $25-50 \mathrm{~km}$. The total column shows clear semi-annual variation in the equatorial region and annual summer maxima with strongest maxima at the southern latitudes.

As pointed in Hauchecorne et al. (2005), the $\mathrm{NO}_{3}$ density is controlled by a temperature sensitive reaction $\mathrm{NO}_{2}+\mathrm{O}_{3} \rightarrow \mathrm{NO}_{3}+\mathrm{O}_{2}$. The correlation between temperature and $\mathrm{NO}_{3}$ is shown in Fig. 29 The correlation in $30-45 \mathrm{~km}$ is high except the at mid-latitudes during winter when very little $\mathrm{NO}_{3}$ can be found.

During nighttime ozone and $\mathrm{NO}_{3}$ are nearly in equilibrium and their ratio can be approximated by (Eq. (5.173) in Brasseur and Solomon, 2005)

$$
\frac{\rho_{\mathrm{NO}_{3}}}{\rho_{\mathrm{O}_{3}}}=\frac{b_{9}}{\rho b_{12}}
$$

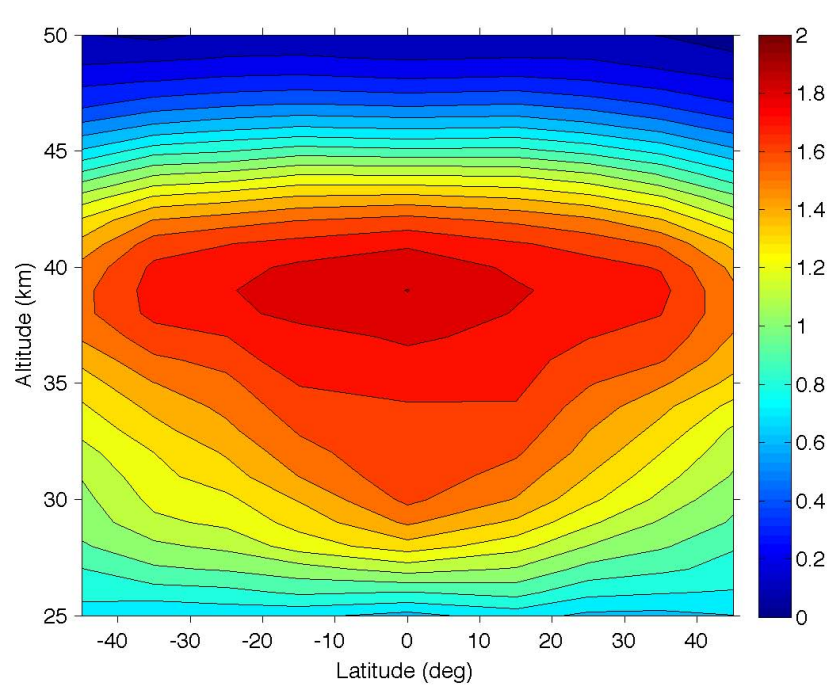

Fig. 25. The $\mathrm{NO}_{3}$ constant term $c(z)$ of the time series as a function of latitude and altitude. The scale is $10^{7} \mathrm{~cm}^{-3}$.

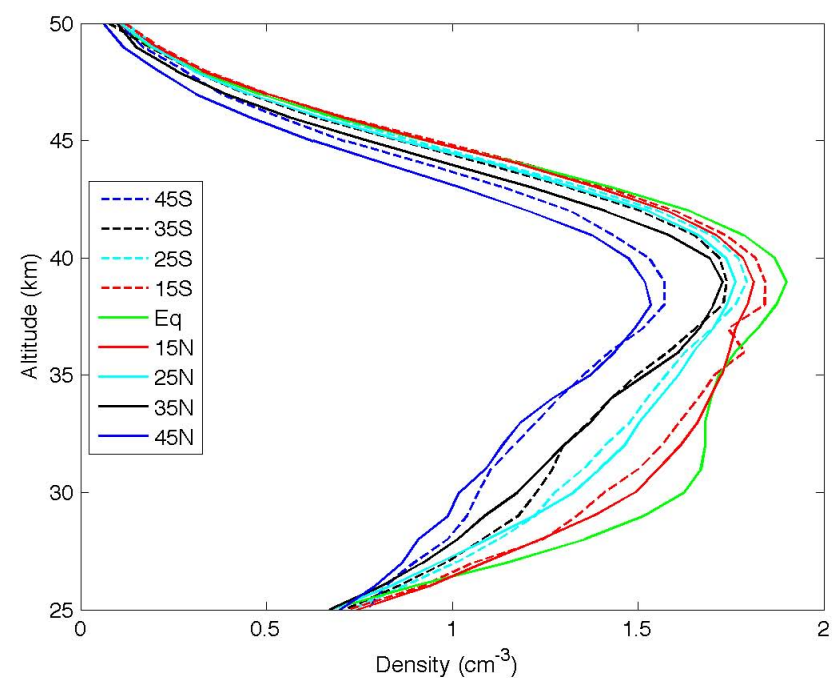

Fig. 26. The $\mathrm{NO}_{3}$ constant term $c(z)$ as a function of altitude for several latitude belts. The profile values are scaled by $10^{7}$.

where $\rho$ is the neutral density. The coefficient $b_{9}$ is the rate coefficient for $\mathrm{NO}_{2}+\mathrm{O}_{3} \rightarrow \mathrm{NO}_{3}+\mathrm{O}_{2}$ and $b_{12}$ for $\mathrm{NO}_{3}+\mathrm{NO}_{2}$ $+\mathrm{M} \rightarrow \mathrm{N}_{2} \mathrm{O}_{5}+\mathrm{M}$. Both depend on temperature. We have calculated the ratio Eq. (4) using GOMOS monthly data for the same latitude belts used in Figs. 4 and 23. Taking the median over times the experimental and theoretical value are inside $20 \%$ from each other below $40 \mathrm{~km}$ for all latitude regions but deviate strongly at higher altitudes. 


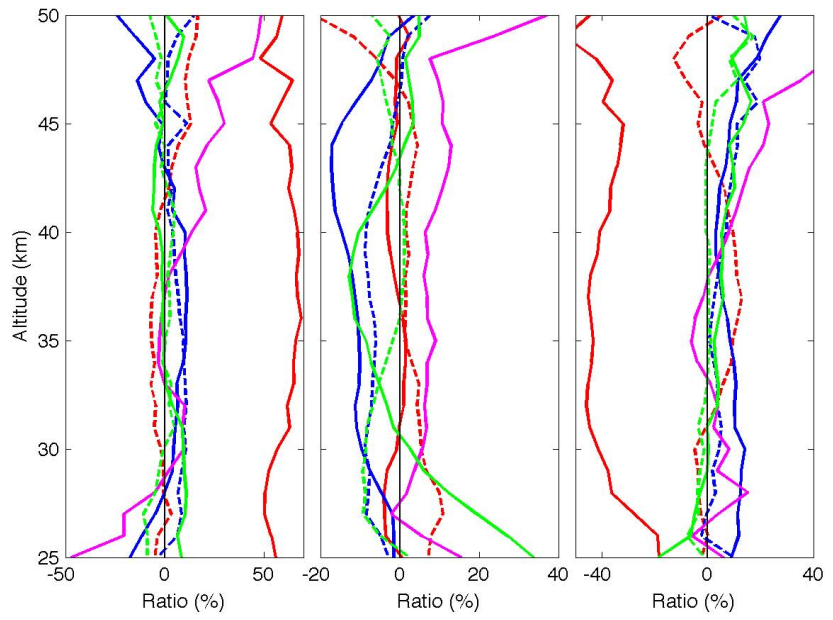

Fig. 27. $\mathrm{NO}_{3}$ fitting components as a function of altitude in three latitude belts in the stratosphere. All amplitudes have been given as a ratio between the original amplitude in Eq. (2) and the the constant term $c(z)$ in Eq. (2) and given in \%. Line identifications: Annual $\left(a_{1}\right.$ and $\left.b_{1}\right)$ : solid and dashed red, respectively, Semi-annual $\left(a_{2}\right.$ and $\left.b_{2}\right)$ : solid and dashed blue, respectively, QBO $10 \mathrm{hPa}\left(q_{1}\right)$ and $30 \mathrm{hPa}\left(q_{2}\right)$ : solid and dashed green, respectively, solar $(s)$ : solid magenta. The zero value line has been shown by a thin black line. Left: $50^{\circ} \mathrm{S}-40^{\circ} \mathrm{S}$, Middle: $10^{\circ} \mathrm{S}-10^{\circ} \mathrm{N}$, Right: $40^{\circ} \mathrm{N}-50^{\circ} \mathrm{N}$. Note that the $\mathrm{x}$-axis ranges vary in panels.

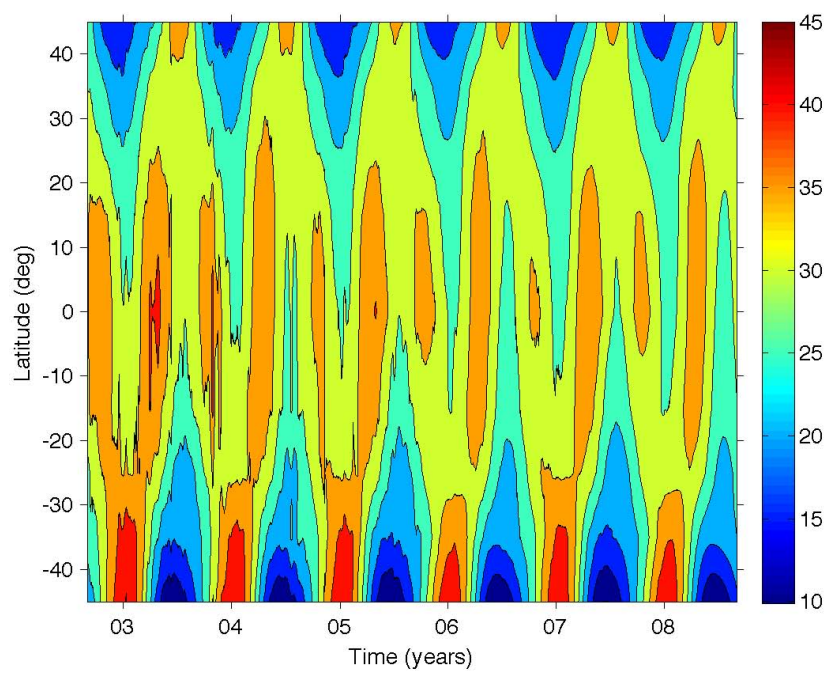

Fig. 28. The daily vertical partial $\mathrm{NO}_{3}$ column in $25-50 \mathrm{~km}$ as a function of time and latitude The column is calculated from the time series and scaled by $10^{12}$ molecules $\mathrm{cm}^{-2}$.

\section{Conclusions}

In this paper we have analysed 6 years of GOMOS measurements of $\mathrm{O}_{3}, \mathrm{NO}_{2}$, and $\mathrm{NO}_{3}$. We constructed monthly and daily time series for the vertical profiles using GOMOS nighttime measurements. The daily time series were first examined for consistency by comparing time series from dif-

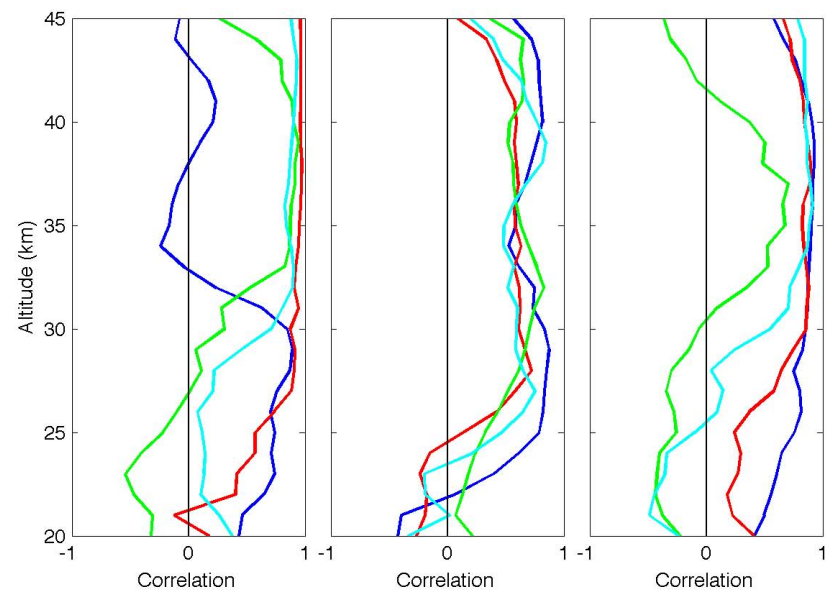

Fig. 29. Correlations of the monthly GOMOS $\mathrm{NO}_{3}$ median densities with the monthly median temperatures (from ECMWF) as a function of altitude. Left: $30^{\circ} \mathrm{S}-50^{\circ} \mathrm{S}$, Middle: $10^{\circ} \mathrm{S}-10^{\circ} \mathrm{N}$, Right: $30^{\circ} \mathrm{N}-50^{\circ} \mathrm{N}$. Line identifications: DJF: blue, MAM: red, JJA: green, SON: cyan.

ferent stars. For ozone we found 57 stars that were not able to provide consistent ozone profile data in $15-100 \mathrm{~km}$ for the whole 6 year period. For $\mathrm{NO}_{2}$ and $\mathrm{NO}_{3}$ all stars were found useful in the $20-50 \mathrm{~km}$ height range. The latitudinal area analysed was restricted to $50^{\circ} \mathrm{S}-50^{\circ} \mathrm{N}$ to get continuous time coverage. The polar regions were not investigated as night (or day) measurements alone cannot provide continuous coverage. Studies of GOMOS measurements of $\mathrm{O}_{3}$, $\mathrm{NO}_{2}$, and $\mathrm{NO}_{3}$ in the polar regions can be found, for example, in Verronen et al. (2006), Seppälä et al. (2007), Tétard et al. (2009), and Sofieva et al. (2009).

We analysed the daily time series of $\mathrm{O}_{3}, \mathrm{NO}_{2}$, and $\mathrm{NO}_{3}$ profiles by fitting the series by a time independent constant term, annual and semi-annual terms, a solar proxy and two QBO proxies. We did not include a linear trend term in our model because the length of the data set turned out to be too short to distinguish the linear variation and the solar variation. The fitting has been based on daily median values in latitude belts. The fit was also performed using monthly values and the results were found to be close to daily results. The importance of the various terms was examined by calculating $R^{2}$ and $\chi^{2}$ values for fits. For all three constituents the constant term, annual and semi-annual term were easily determined. For ozone the QBO terms were found important in the equatorial stratosphere. Because of the shortness of the period considered, the fitting of the solar term did not make significant improvement in the stratospheric ozone time series but in the MLT we found large declining trends from the solar contribution. For $\mathrm{NO}_{2}$ both the QBO and the solar term improved the fits at all latitudes. For $\mathrm{NO}_{3}$ only the QBO improved the fit. The $\mathrm{NO}_{3}$ distribution below $40 \mathrm{~km}$ was found to be controlled to a large extent by temperature and ozone. Notice that a paper by Hauchecorne et al. (2010) 
in this special volume investigates the role of $\mathrm{QBO}$ and temperature in tropical ozone, $\mathrm{NO}_{2}$ and $\mathrm{NO}_{3}$ distributions measured by GOMOS.

In our analysis we have not taken into account the special local hour sampling patterns of GOMOS. This omission may affect the latitude distributions of MLT ozone and stratospheric $\mathrm{NO}_{2}$ and $\mathrm{NO}_{3}$. The diurnal effect could be addressed by classifying data according to the local hour of measurement but this obviously reduces the statistical accuracy of results.

The GOMOS data set presented here can provide new valuable nighttime climatologies for $\mathrm{O}_{3}, \mathrm{NO}_{2}$, and $\mathrm{NO}_{3}$ profiles. Preliminary yearly climatological data sets can be found at http://fmilimb.fmi.fi/. For stratospheric ozone there are already several climatologies like Fortuin and Kelder (1998); Brunner et al. (2006); Randel and Wu (2007); McPeters et al. (2007); Hassler et al. (2008). In Kyrölä et al. (2006) we have made comparison of GOMOS 2003 results with the Fortuin-Kelder results but the comparison of the present 6 year GOMOS data set with the aforementioned climatologies requires a new study. The GOMOS MLT ozone data climatology is unique but a similar data set can be constructed from SABER measurements. Comparisons of MLT data with models will be very interesting as many processes in the MLT are still much more uncertain than the ones in the stratosphere. For $\mathrm{NO}_{2}$ there exist a recent climatology of Brohede et al. $(2007,2008)$. The $\mathrm{NO}_{3}$ GOMOS data set is unique as most of the other instruments need sunlight to work and there is very little $\mathrm{NO}_{3}$ during daytime.

Acknowledgements. We want to thank both the referees for useful comments. We want to thank also Anne Smith, Dan Marsh, Martin Kaufman, Leif Backman, Marko Laine, Laura Thölix and Esko Kyrö for valuable discussions.

Edited by: M. Van Roozendael

\section{References}

Bertaux, J. L., Megie, G., Widemann, T., Chassefiere, E., Pellinen, R., Kyrölä, E., Korpela, S., and Simon, P.: Monitoring of Ozone Trend by Stellar Occultations: The GOMOS Instrument, Adv. Space Res., 11, 237-242, 1991.

Bertaux, J. L., Kyrölä, E., and Wehr, T.: Stellar Occultation Technique for Atmospheric Ozone Monitoring: GOMOS on Envisat, Earth Observation Quarterly, 67, 17-20, 2000.

Bertaux, J. L., Hauchecorne, A., Dalaudier, F., Cot, C., Kyrölä, E., Fussen, D., Tamminen, J., Leppelmeier, G. W., Sofieva, V., Hassinen, S., d'Andon, O. F., Barrot, G., Mangin, A., Théodore, B., Guirlet, M., Korablev, O., Snoeij, P., Koopman, R., and Fraisse, R.: First results on GOMOS/Envisat, Adv. Space Res., 33, 1029_ 1035, 2004.

Bertaux, J. L., Kyrölä, E., Fussen, D., Hauchecorne, A., Dalaudier, F., Sofieva, V., Tamminen, J., Vanhellemont, F., Fanton d'Andon, O., Barrot, G., Mangin, A., Blanot, L., Lebrun, J. C., Pérot, K., Fehr, T., Saavedra, L., and Fraisse, R.: Global ozone monitoring by occultation of stars: an overview of GOMOS measurements on ENVISAT, Atmos. Chem. Phys. Discuss., 10, 9917-10076, doi:10.5194/acpd-10-9917-2010, 2010.

Bracher, A., Sinnhuber, M., Rozanov, A., and Burrows, J. P.: Using a photochemical model for the validation of $\mathrm{NO}_{2}$ satellite measurements at different solar zenith angles, Atmos. Chem. Phys., 5, 393-408, doi:10.5194/acp-5-393-2005, 2005.

Brasseur, G. P. and Solomon, S.: Aeronomy of the Middle Atmosphere, Springer, Dordrecht, 3rd revised and enlarged edn., 2005.

Brohede, S., McLinden, C. A., Berthet, G., Haley, C. S., Murtagh, D., and Sioris, C. E.: A stratospheric $\mathrm{NO}_{2}$ climatology from Odin/OSIRIS limb-scatter measurements, Can. J. Phys., 85, 1253-1274, doi:10.1139/P07-141, 2007.

Brohede, S., McLinden, C. A., Urban, J., Haley, C. S., Jonsson, A. I., and Murtagh, D.: Odin stratospheric proxy NOy measurements and climatology, Atmos. Chem. Phys., 8, 5731-5754, doi:10.5194/acp-8-5731-2008, 2008.

Brunner, D., Staehelin, J., Maeder, J. A., Wohltmann, I., and Bodeker, G. E.: Variability and trends in total and vertically resolved stratospheric ozone based on the CATO ozone data set, Atmos. Chem. Phys., 6, 4985-5008, doi:10.5194/acp-6-49852006, 2006.

Dessler, A.: The chemistry and physics of stratospheric ozone, Academic Press, 2000.

Dhomse, S., Weber, M., Wohltmann, I., Rex, M., and Burrows, J. P.: On the possible causes of recent increases in northern hemispheric total ozone from a statistical analysis of satellite data from 1979 to 2003, Atmos. Chem. Phys., 6, 1165-1180, doi:10.5194/acp-6-1165-2006, 2006.

Dupuy, E., Walker, K. A., Kar, J., Boone, C. D., McElroy, C. T., Bernath, P. F., Drummond, J. R., Skelton, R., McLeod, S. D., Hughes, R. C., Nowlan, C. R., Dufour, D. G., Zou, J., Nichitiu, F., Strong, K., Baron, P., Bevilacqua, R. M., Blumenstock, T., Bodeker, G. E., Borsdorff, T., Bourassa, A. E., Bovensmann, H., Boyd, I. S., Bracher, A., Brogniez, C., Burrows, J. P., Catoire, V., Ceccherini, S., Chabrillat, S., Christensen, T., Coffey, M. T., Cortesi, U., Davies, J., De Clercq, C., Degenstein, D. A., De Mazière, M., Demoulin, P., Dodion, J., Firanski, B., Fischer, H., Forbes, G., Froidevaux, L., Fussen, D., Gerard, P., Godin-Beekmann, S., Goutail, F., Granville, J., Griffith, D., Haley, C. S., Hannigan, J. W., Höpfner, M., Jin, J. J., Jones, A., Jones, N. B., Jucks, K., Kagawa, A., Kasai, Y., Kerzenmacher, T. E., Kleinböhl, A., Klekociuk, A. R., Kramer, I., Kllmann, H., Kuttippurath, J., Kyrölä, E., Lambert, J.-C., Livesey, N. J., Llewellyn, E. J., Lloyd, N. D., Mahieu, E., Manney, G. L., Marshall, B. T., McConnell, J. C., McCormick, M. P., McDermid, I. S., McHugh, M., McLinden, C. A., Mellqvist, J., Mizutani, K., Murayama, Y., Murtagh, D. P., Oelhaf, H., Parrish, A., Petelina, S. V., Piccolo, C., Pommereau, J.-P., Randall, C. E., Robert, C., Roth, C., Schneider, M., Senten, C., Steck, T., Strandberg, A., Strawbridge, K. B., Sussmann, R., Swart, D. P. J., Tarasick, D. W., Taylor, J. R., Tétard, C., Thomason, L. W., Thompson, A. M., Tully, M. B., Urban, J., Vanhellemont, F., Vigouroux, C., von Clarmann, T., von der Gathen, P., von Savigny, C., Waters, J. W., Witte, J. C., Wolff, M., and Zawodny, J. M.: Validation of ozone measurements from the Atmospheric Chemistry Experiment (ACE), Atmos. Chem. Phys., 9, 287-343, doi:10.5194/acp9-287-2009, 2009.

ESA: Envisat-GOMOS, An instrument for global atmospheric 
ozone monitoring, vol. SP-1244, European Space Agency, 2001.

Fortuin, J. P. F. and Kelder, H.: An ozone climatology based on ozonesonde and satellite measurements, J. Geophys. Res., 103, 31709-31734, 1998.

Harris, N., Hudson, R., and Phillips, C.: Assessment of trends in the vertical distribution of ozone, WMO, Geneva, 1999.

Hassler, B., Bodeker, G. E., and Dameris, M.: Technical Note: A new global database of trace gases and aerosols from multiple sources of high vertical resolution measurements, Atmos. Chem. Phys., 8, 5403-5421, doi:10.5194/acp-8-5403-2008, 2008.

Hauchecorne, A., Bertaux, J.-L., Dalaudier, F., Cot, C., Lebrun, J.C., Bekki, S., Marchand, M., Kyrölä, E., Tamminen, J., Sofieva, V., Fussen, D., Vanhellemont, F., Fanton d'Andon, O., Barrot, G., Mangin, A., Théodore, B., Guirlet, M., Snoeij, P., Koopman, R., Saavedra de Miguel, L., Fraisse, R., and Renard, J.B.: First simultaneous global measurements of nighttime stratospheric $\mathrm{NO}_{2}$ and $\mathrm{NO}_{3}$ observed by Global Ozone Monitoring by Occultation of Stars (GOMOS)/Envisat in 2003, J. Geophys. Res., 110, D18301, doi:10.1029/2004JD005711, 2005.

Hauchecorne, A., Bertaux, J. L., Dalaudier, F., Keckhut, P., Lemennais, P., Bekki, S., Marchand, M., Lebrun, J. C., Kyrölä, E., Tamminen, J., Sofieva, V., Fussen, D., Vanhellemont, F., Fanton d'Andon, O., Barrot, G., Blanot, L., Fehr, T., and Saavedra de Miguel, L.: Response of tropical stratospheric $\mathrm{O}_{3}, \mathrm{NO}_{2}$ and $\mathrm{NO}_{3}$ to the equatorial Quasi-Biennial Oscillation and to temperature as seen from GOMOS/ENVISAT, Atmos. Chem. Phys. Discuss., 10, 9153-9171, doi:10.5194/acpd-10-9153-2010, 2010.

Hood, L. L. and Soukharev, B. E.: Solar induced variations of odd nitrogen: Multiple regression analysis of UARS HALOE data, Geophys. Res. Lett., 33, L22805, doi:10.1029/2006GL028122, 2006.

Huang, F. T., Mayr, H. G., Russell, J. M., Mlynczak, M. G., and Reber, C. A.: Ozone diurnal variations and mean profiles in the mesosphere, lower thermosphere, and stratosphere, based on measurements from SABER on TIMED, Journal of Geophysical Research (Space Physics), 113, A04307, doi:10.1029/ 2007JA012739, 2008.

Jones, A., Urban, J., Murtagh, D. P., Eriksson, P., Brohede, S., Haley, C., Degenstein, D., Bourassa, A., von Savigny, C., Sonkaew, T., Rozanov, A., Bovensmann, H., and Burrows, J.: Evolution of stratospheric ozone and water vapour time series studied with satellite measurements, Atmos. Chem. Phys., 9, 6055-6075, doi:10.5194/acp-9-6055-2009, 2009.

Kerzenmacher, T., Wolff, M. A., Strong, K., Dupuy, E., Walker, K. A., Amekudzi, L. K., Batchelor, R. L., Bernath, P. F., Berthet, G., Blumenstock, T., Boone, C. D., Bramstedt, K., Brogniez, C., Brohede, S., Burrows, J. P., Catoire, V., Dodion, J., Drummond, J. R., Dufour, D. G., Funke, B., Fussen, D., Goutail, F., Griffith, D. W. T., Haley, C. S., Hendrick, F., Höpfner, M., Huret, N., Jones, N., Kar, J., Kramer, I., Llewellyn, E. J., López-Puertas, M., Manney, G., McElroy, C. T., McLinden, C. A., Melo, S., Mikuteit, S., Murtagh, D., Nichitiu, F., Notholt, J., Nowlan, C., Piccolo, C., Pommereau, J.-P., Randall, C., Raspollini, P., Ridolfi, M., Richter, A., Schneider, M., Schrems, O., Silicani, M., Stiller, G. P., Taylor, J., Tétard, C., Toohey, M., Vanhellemont, F., Warneke, T., Zawodny, J. M., and Zou, J.: Validation of $\mathrm{NO}_{2}$ and NO from the Atmospheric Chemistry Experiment (ACE), Atmos. Chem. Phys., 8, 5801-5841, doi:10.5194/acp-8-5801-2008, 2008.
Ko, M. K. W., Sze, N.-D., and Weisenstein, D. K.: The roles of dynamical and chemical processes in determining the stratospheric concentration of ozone in one-dimensional and twodimensional models, J. Geophys. Res., 94, 9889-9896, doi: 10.1029/JD094iD07p09889, 1989.

Kyrölä, E., Tamminen, J., Leppelmeier, G. W., Sofieva, V., Hassinen, S., Bertaux, J.-L., Hauchecorne, A., Dalaudier, F., Cot, C., Korablev, O., d'Andon, O. F., Barrot, G., Mangin, A., Theodore, B., Guirlet, M., Etanchaud, F., Snoeij, P., Koopman, R., Saavedra, L., Fraisse, R., Fussen, D., and Vanhellemont, F.: GOMOS on Envisat: An overview, Adv. Space Res., 33, 1020-1028, 2004.

Kyrölä, E., Tamminen, J., Leppelmeier, G. W., Sofieva, V., Hassinen, S., Seppälä, A., Verronen, P. T., Bertaux, J.-L., Hauchecorne, A., Dalaudier, F., Fussen, D., Vanhellemont, F., d'Andon, O. F., Barrot, G., Mangin, A., Theodore, B., Guirlet, M., Koopman, R., Saavedra, L., Snoeij, P., and Fehr, T.: Nighttime ozone profiles in the stratosphere and mesosphere by the Global Ozone Monitoring by Occultation of Stars on Envisat, J. Geophys. Res., 111, D24306, doi:10.1029/2006JD007193, 2006.

Kyrölä, E., Tamminen, J., Sofieva, V., Bertaux, J. L., Hauchecorne, A., Dalaudier, F., Fussen, D., Vanhellemont, F., Fanton d'Andon, O., Barrot, G., Guirlet, M., Mangin, A., Blanot, L., Fehr, T., Saavedra de Miguel, L., and Fraisse, R.: Retrieval of atmospheric parameters from GOMOS data, Atmos. Chem. Phys. Discuss., 10, 10145-10217, doi:10.5194/acpd-10-10145-2010, 2010.

Marsh, D. R., Garcia, R. R., Kinnison, D. E., Boville, B. A., Sassi, F., Solomon, S. C., and Matthes, K.: Modeling the whole atmosphere response to solar cycle changes in radiative and geomagnetic forcing, J. Geophys. Res.-Atmos., 112, D23306, doi: 10.1029/2006JD008306, 2007.

McPeters, R. D., Labow, G. J., and Logan, J. A.: Ozone climatological profiles for satellite retrieval algorithms, J. Geophys. Res.-Atmos., 112, D05308, doi:10.1029/2005JD006823, 2007.

Meijer, Y. J., Swart, D. P. J., Allaart, M., Andersen, S. B., Bodeker, G., Boyd, Braathena, G., Calisesia, Y., Claude, H., Dorokhov, V., von der Gathen, P., Gil, M., Godin-Beekmann, S., Goutail, F., Hansen, G., Karpetchko, A., Keckhut, P., Kelder, H. M., Koelemeijer, R., Kois, B., Koopman, R. M., Lambert, J.-C., Leblanc, T., McDermid, I. S., Pal, S., Kopp, G., Schets, H., Stubi, R., Suortti, T., Visconti, G., and Yela, M.: Pole-to-pole validation of ENVISAT/GOMOS ozone profiles using data from groundbased and balloon-sonde measurements, J. Geophys. Res., 109, D23305, doi:10.1029/2004JD004834, 2004.

Perliski, L. M., Solomon, S., and London, J.: On the interpretation of seasonal variations of stratospheric ozone, Planet. Space Sci., 37, 1527-1538, doi:10.1016/0032-0633(89)90143-8, 1989.

Randel, W. J. and Wu, F.: A stratospheric ozone profile data set for 1979-2005: Variability, trends, and comparisons with column ozone data, J. Geophys. Res.-Atmos., 112, D06313, doi:10.1029/ 2006JD007339, 2007.

Renard, J., Berthet, G., Brogniez, C., Catoire, V., Fussen, D., Goutail, F., Oelhaf, H., Pommereau, J., Roscoe, H. K., Wetzel, G., Chartier, M., Robert, C., Balois, J., Verwaerde, C., Auriol, F., François, P., Gaubicher, B., and Wursteisen, P.: Validation of GOMOS-Envisat vertical profiles of $\mathrm{O}_{3}, \mathrm{NO}_{2}, \mathrm{NO}_{3}$, and aerosol extinction using balloon-borne instruments and analysis of the retrievals, Journal of Geophysical Research (Space Physics), 113, A02302, doi:10.1029/2007JA012345, 2008. 
Seppälä, A., Verronen, P. T., Clilverd, M. A., Randall, C. E., Tamminen, J., Sofieva, V. F., Backman, L., and Kyrölä, E.: Arctic and Antarctic polar winter $\mathrm{NO}_{\mathrm{x}}$ and energetic particle precipitation in 2002-2006, Geophys. Res. Lett., 34, L12810, doi: 10.1029/2007GL029733, 2007.

Smith, A. K.: Physics and chemistry of the mesopause region, J. Atmos. Sol.-Terr. Phys., 66, 839-857, 2004.

Smith, A. K., Marsh, D. R., Russell, J. M., Mlynczak, M. G., Martin-Torres, F. J., and Kyrölä, E.: Satellite observations of high nighttime ozone at the equatorial mesopause, J. Geophys. Res.-Atmos., 113, D17312, doi:10.1029/2008JD010066, 2008.

Sofieva, V. F., Kyrölä, E., Verronen, P. T., Seppälä, A., Tamminen, J., Marsh, D. R., Smith, A. K., Bertaux, J.-L., Hauchecorne, A., Dalaudier, F., Fussen, D., Vanhellemont, F., Fanton d'Andon, O., Barrot, G., Guirlet, M., Fehr, T., and Saavedra, L.: Spatiotemporal observations of the tertiary ozone maximum, Atmos. Chem. Phys., 9, 4439-4445, doi:10.5194/acp-9-4439-2009, 2009.

Soukharev, B. E. and Hood, L. L.: Solar cycle variation of stratospheric ozone: Multiple regression analysis of long-term satellite data sets and comparisons with models, J. Geophys. Res.Atmos., 111, D20314, doi:10.1029/2006JD007107, 2006.

Tamminen, J., Kyrölä, E., Sofieva, V. F., Laine, M., Bertaux, J.-L., Hauchecorne, A., Dalaudier, F., Fussen, D., Vanhellemont, F., Fanton-d'Andon, O., Barrot, G., Mangin, A., Guirlet, M., Blanot, L., Fehr, T., Saavedra de Miguel, L., and Fraisse, R.: GOMOS data characterization and error estimation, Atmos. Chem. Phys. Discuss., 10, 6755-6796, doi:10.5194/acpd10-6755-2010, 2010.
Tétard, C., Fussen, D., Bingen, C., Capouillez, N., Dekemper, E., Loodts, N., Mateshvili, N., Vanhellemont, F., Kyrölä, E., Tamminen, J., Sofieva, V., Hauchecorne, A., Dalaudier, F., Bertaux, J.-L., Fanton d'Andon, O., Barrot, G., Guirlet, M., Fehr, T., and Saavedra, L.: Simultaneous measurements of $\mathrm{OClO}, \mathrm{NO}_{2}$ and $\mathrm{O}_{3}$ in the Arctic polar vortex by the GOMOS instrument, Atmos. Chem. Phys., 9, 7857-7866, doi:10.5194/acp-9-7857-2009, 2009.

Verronen, P. T., Kyrölä, E., Tamminen, J., Funke, B., Gil-López, S., Kaufmann, M., López-Puertas, M., von Clarmann, T., Stiller, G., Grabowski, U., and Höpfner, M.: A comparison of nighttime GOMOS and MIPAS ozone profiles in the stratosphere and mesosphere, Adv. Space Res., 36, 958-966, 2005.

Verronen, P. T., Seppälä, A., Kyrölä, E., Tamminen, J., Pickett, H. M., and Turunen, E.: Production of odd hydrogen in the mesosphere during the January 2005 solar proton event, Geophys. Res. Lett., 33, L24811, doi:10.1029/2006GL028115, 2006.

Verronen, P. T., Ceccherini, S., Cortesi, U., Kyrölä, E., and Tamminen, J.: Statistical comparison of night-time $\mathrm{NO}_{2}$ observations in 2003-2006 from GOMOS and MIPAS instruments, Adv. Space Res., 43, 1918-1925, doi:10.1016/j.asr.2009.01.027, 2009.

WMO: Scientific Assessment of Ozone Depletion: 2006, Global Ozone Research and Monitoring Project - Report No. 50, World Meteorological Organization, Geneva, Switzerland, 2007. 